University of Wollongong

Research Online

Faculty of Business - Papers (Archive)

Faculty of Business and Law

$1-1-2019$

\title{
Loan financing and investment in princeling-backed firms
}

Qing Li

University of Wollongong, q1684@uowmail.edu.au

Qigui Liu

Zhejiang University, qigui@uow.edu.au

Shiguang $\mathrm{Ma}$

University of Wollongong, shiguang@uow.edu.au

Gary G. Tian

Macquarie University, gtian@uow.edu.au

Follow this and additional works at: https://ro.uow.edu.au/buspapers

Part of the Business Commons

Research Online is the open access institutional repository for the University of Wollongong. For further information contact the UOW Library: research-pubs@uow.edu.au 


\title{
Loan financing and investment in princeling-backed firms
}

\author{
Abstract \\ This study investigates the role of princelings in Chinese listed firms. Our findings suggest that \\ princelings ensure better access to bank loans for non-SOEs but bring no significant benefits to SOEs. Our \\ empirical results further indicate that bank lending decisions are distorted for princeling-backed firms due \\ to the privileges and protections they can obtain from the higher levels of the government through \\ princelings' family ties. Moreover, we find that, due to excess long-term bank loans, princeling-backed \\ non-SOEs tend to overinvest, which ultimately results in lower investment efficiency. Furthermore, we use \\ the difference-in-difference method to capture the effect of the exogenous shock of the recent anti- \\ corruption campaign in China on princelings and corporate finance and investment. We demonstrate that \\ the anti-corruption campaign launched by the Chinese government in 2012 effectively weakened the \\ power of princeling connections. Overall, our study suggests that by distorting bank lending decisions and \\ encouraging overinvestment, the involvement of princelings in firms causes resource misallocation which \\ favours princeling-backed firms and discourages investment in non-princeling-backed firms.

\section{Disciplines} \\ Business \\ Publication Details \\ Li, Q., Liu, Q., Ma, S. \& Tian, G. G. (2019). Loan financing and investment in princeling-backed firms. \\ Pacific-Basin Finance Journal, 56 71-92.
}




\title{
Loan Financing and Investment in Princeling-backed firms
}

\author{
Qing Li ${ }^{\mathrm{a}}$, Qigui Liu ${ }^{\mathrm{b}}$, Shiguang Ma ${ }^{\mathrm{a}, *}$, Gary Gang Tianc

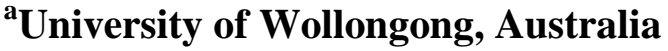 \\ b'Zhejiang University, China \\ ${ }^{c}$ Macquarie University, Australia
}

\begin{abstract}
This study investigates the role of princelings in Chinese listed firms. Our findings suggest that princelings ensure better access to bank loans for non-SOEs but bring no significant benefits to SOEs. Our empirical results further indicate that bank lending decisions are distorted for princeling-backed firms due to the privileges and protections they can obtain from the higher levels of the government through princelings' family ties. Moreover, we find that, due to excess long-term bank loans, princeling-backed non-SOEs tend to overinvest, which ultimately results in lower investment efficiency. Furthermore, we use the difference-in-difference method to capture the effect of the exogenous shock of the recent anticorruption campaign in China on princelings and corporate finance and investment. We demonstrate that the anti-corruption campaign launched by the Chinese government in 2012 effectively weakened the power of princeling connections. Overall, our study suggests that by distorting bank lending decisions and encouraging overinvestment, the involvement of princelings in firms causes resource misallocation which favours princeling-backed firms and discourages investment in non-princeling-backed firms.
\end{abstract}

Keywords: Princelings, princeling-backed firms, political connections, bank loans, investment

JEL classification: D22, G32, G34, G38

\footnotetext{
* Corresponding Author. Email addresses: qingli@uow.edu.au (Qing Li), qigui@zju.edu.cn (Qigui Liu), shiguang@uow.edu.au (Shiguang Ma), gary.tian@mafc.mq.edu.au (Gary Gang Tian). We would like to acknowledge the helpful comments received from the participants in the 30th Asian Finance Association Annual Meeting and the 30th CESA Annual Conference. We thank the anonymous reviewer for her/his suggestions and appreciate the guidance from the guest editors Professor Jing Shi and Professor Wenxuan Hou.
} 


\section{Introduction}

Social networks have always been an essential component of human societies. When it comes to the field of corporate finance, we are interested in the influence of such relationships on corporate operations. The extant literature has identified several types of networks that have impacts on individual firms, including alumni connections, professional connections, social connections (local ties), legal and business connections, and political connections in diverse forms (Maciel and Camargo, 2016; Mogiliansky, 2001) ${ }^{1}$. Among others, political connections play a non-negligible role in firms in both developed and developing economies. In developed economies like the United States, lobbying activities are a typical form of political connections at the firm level (Bennedsen and Feldmann, 2006; Drazen el al., 2007). In emerging countries like China, political connections usually exist through executives having prior experience working for the government. This form of political connections, which are referred to as normal political connections in this paper, has been thoroughly investigated in the literature.

In addition to the aforementioned normal political connections, there are "princelings connections" that are even more powerful in the Chinese market. This “princelings connections” are proposed as a new form of political connections in this paper. A firm with princeling shareholders or executives is considered to possess princeling connections. The term "princelings" refers to descendants of former senior bureaucrats of the Chinese Communist Party. They have aroused a heated discussion due to their significant influence on the economy in China, but their impacts have rarely been investigated in an academic manner. As a result of the continuous rule of Chinese Communist Party since the establishment of the nation, successive senior bureaucrats possess great political power, even long after their retirements, and that power is inherited by princelings to some extent. The New York Times published an article in May 2012, entitled “'Princelings” in China Use Family Ties to Gain Riches”. The article declared that princelings were almost routinely included in commercial ventures in today's China. According to the article, "this is how the Communist Party shares the spoils, allowing the relatives of senior leaders to cash in”. For instance, Li Xiaolin (daughter of Li Peng, a former prime minister) is the chairwoman and chief

\footnotetext{
${ }^{1}$ For instance, alumni connections affect stock holding decisions and returns of fund portfolio managers (Cohen and Malloy, 2010), while professional connections help firms to get more trading credit (Liu et al., 2016).
} 
executive of China Power International, one of the five biggest power generating companies in China. Her brother, Li Xiaopeng, was formerly the head of another top electricity company and is now a provincial governor. Over the past two decades, business and politics have become so tightly intertwined that the Communist Party has effectively institutionalized an entire ecosystem of crony capitalism (Barboza and Franiere, 2012).

Princelings do play a big part in the crony system. They are extremely powerful in China because even though laws and regulations prevent senior bureaucrats from misusing their authority, there are still loopholes for their families to take advantage of. To be more specific, incumbent bureaucrats are legally barred from taking any positions in firms and their spouses and children are not allowed to be engaged in any business under the bureaucrats' jurisdiction while they are in power. If incumbent bureaucrats or their family members are caught obtaining personal benefits, they suffer harsh punishments according to the law. In consideration of possible future political careers, and more importantly to be free from having criminal records, incumbent bureaucrats are normally very cautious when they are in power. Therefore, if they intend to obtain personal benefits from their positions, their only choice is to cooperate with their former colleagues and, more commonly, with subordinate officials after their retirement. However, there are strict regulations which prevent former bureaucrats form participating in business activities connected to their former jurisdiction even after their retirement. This means that it is not possible for them to gain benefits directly for themselves. As a result, the descendants of former senior bureaucrats, princelings, are found to be perfect proxies for the elder generation.

Princelings act as representatives of their political families and obtain benefits by utilizing the political networks previously constructed by older family members. Due to their family connections they are able to bribe corrupt bureaucrats in their networks in exchange of privileges and protections for their firms. This motivates princelings to take managerial positions in firms, or simply to establish their own firms. Participating in business activities enables princelings to use their political influence into obtain actual benefits for their firms, as well as for themselves if going a step further, juris et de jure. The other way around, against the institutional background of severe government intervention and relatively weak legal protection for property rights, Chinese firms, especially private enterprises, are subject to strong incentives to establish princelings connections so that they can enjoy privileges and protections 
from the government (Burkart et al., 2003; Morck et al., 2005; Yeh et al., 2013). Nevertheless, the benefits gained by princeling-backed firms are at the cost of nonprinceling-backed firms. As discussed above, since China is an emerging economy in transformation, its financial market is not entirely market-oriented. The government still possesses great controlling power over banks, especially state-owned banks. Therefore, state-owned enterprises (SOEs) are in a favourable position for obtaining loans from banks due to their inherited connections to the government. This means fewer loans are available for non-SOEs. Thus, princeling connections are highly sought after by non-SOEs. Since SOEs and princeling-backed non-SOEs are able to claim larger shares of the limited capital resources, non-princeling-backed non-SOEs are faced with as even harsher financing environment, and this creates an unbalanced and unhealthy economic environment. To target party and government officials suspected of corruption, the Chinese government launched a major anti-corruption campaign at the end of 2012.

Princeling connections, as a complement to normal political connections, are the key subject investigated in this study. The two types of political connections co-exist. On the one hand, the widespread normal political connections are usually identified when firms employ executives with governmental working experience. On the other hand, princeling connections are welcomed by firms as well. The extant literature contains mixed, even conflicting, views on the influence of political connections (Fisman, 2001; Johnson and Mitton, 2003; Faccio, 2006; Fan et al., 2007). The reason for this may be the hidden role of princeling connections. As normal political connections have been relatively broadly established in firms, princeling connections appear to have more influence on competition for resources and loans.

It is true that princeling connections are, to some extent, similar to normal political connections that they both utilize their connections to the government in exchange for personal benefits and help firms to take an advantageous position in the market. Nevertheless, princeling connections are distinguished from normal political connection in the mechanism through which they have impacts on corporate operations. On the one hand, normal political connections refer to executives who have previous working experience in the government. Upon its definition, it is obvious that "experience" of normal political connections is what valued most by firms. Based on their experience, executives of normal political connections are familiar with how government works, for instance the operation of government 
departments or the approval procedure of license or projects (Ferris et al., 2019; Hung et al., 2015). Such experience helps executives to better cooperate with the government in order to achieve their firms' aim. In other words, executives with normal political connections know how to do things in the government's way to win a favourable place. On the other hand, princelings handle this in another way. The reason they are called princelings is their "family ties", and that is their biggest difference from normal political connections. Counting on their fathers or mothers who used to be senior or even top bureaucrats, princelings utilize their family ties to reach out to the incumbent bureaucrats who were their fathers' or mothers' former colleagues or subordinate officials (Chen and Kung, 2019). With their inherited political power, princelings know how to get things done through their ties. Moreover, their networks that cover the government enable them to obtain insider information, which is a real advantage compared to non-princeling-backed firms. To sum up, impacts of princeling connections are released in a way that is more direct and powerful. Since princeling connections are superior to normal political connections, we would expect their significant impacts in addition to normal political connections when they co-exist in firms.

The impacts of princeling connections are examined from four perspectives: (1) impacts on the level of access to bank loans in individual firms; (2) impacts on bank lending decisions; (3) impacts on corporate investment decisions; (4) the influence of the anti-corruption campaign on the role of princeling connections. Firstly, since many studies have shown that normal political connections do have great positive impacts on corporate financing, we hypothesise that princeling connections have unique effects in addition to these normal political connections. This hypothesis can also be inferred from the institutional background mentioned above. Secondly, we hypothesise that princeling connections have significant impacts on bank lending decisions because firms with government support are always considered to be better debtors by banks. Thirdly, if princeling-backed firms are supposed to get more bank loans, it is reasonable to assume that the excess capital is transferred into investment expenditure, and that this affects investment efficiency. Finally, to justify the fundamental fact that the benefits brought by princeling connections depend on bribery and corruption, a comparison between the empirical results before and after the anti-corruption campaign is made.

The results of our regression models, consistent with our hypotheses, suggest 
that princeling connections do have major impacts on multiple aspects of corporate operations. First of all, princeling connections generally improve princeling-backed firms' access to bank loans, especially if they are non-SOEs, which is at the cost of non-princeling-backed firms. Secondly, according to the test results on bank lending decisions, banks prefer princeling-backed firms regardless of their profitability. Thirdly, the empirical results show that princeling-backed firms, holding better access to long-term bank loans which are afterwards converted into investment capital, tend to overinvest. As a result, weakened relationship between investment growth and investment opportunity impairs investment efficiency in princeling-backed firms. Fourthly, we use the difference-in-difference method to capture the effect of the exogenous shock of the recent anticorruption campaign in China on princelings and corporate finance and investment and find that the anti-corruption campaign effectively changed the impacts of princeling connections, creating a fairer and more balanced economic environment. Moreover, princeling executives are found to be more powerful than princeling shareholders, due to their responsibility in corporate management and operations. Last but not least, princeling connections were found be more powerful than normal political connections.

This study contributes to the literature in the following ways. Firstly, to the best of our knowledge, the impacts of princeling connections on corporate financing and investment are academically investigated for the first time in this study. The role and impacts of princeling connections, as phenomena distinct from normal political connections, have long been neglected. The analysis of princeling connections gives us an insight into the typical rent-seeking behaviour of corrupted government bureaucrats. Furthermore, based on agency theory, princelings are divided into two groups in regard to their different roles in corporate operations. The empirical results and discussion on princeling shareholders as principals and princeling executives as agents contribute to agency theory from a unique perspective. More importantly, we also explore the co-existence of princeling connections and normal political connections by examining and comparing their individual impacts on bank loans and investment activities. This paper views princeling connections as complementary to normal political connections, and this facilitates a comprehensive understanding of the role of political connections. 


\section{Hypothesis development}

\subsection{Princeling connections and bank loans}

As the world's largest emerging economy, China is making every effort to improve its economic environment. However, despite decades of progressive achievements in economic reform, China is still identified as a transforming economy with a high level of government intervention over various dimensions, including the allocation of key resources. Studies have found that good relationships with the government provide firms with preferential access to government subsidies, financing opportunities, investment opportunities, and protection from expropriation by the government (Chen, 2011; De Soto, 1990; Shleifer and Vishny, 1993, 1994). Therefore, on the one hand, firms experience strong incentives to establish connections with the government to obtain privileges and protection. They also expect additional benefits from the connections, for instance favourable conditions when borrowing loans, exemption from taxes, and winning government contracts. For these tempting terms, firms are willing to sacrifice a small part of their earnings. On the other hand, government bureaucrats are stimulated to take advantage of their political power for personal benefit. They are able to provide convenience to firms under their jurisdiction due to their power over resource allocation and project approvals. Even though both sides are eager to 'cooperate', laws always act as a barrier between them to prevent the trade-off between money and power, and to protect the rights of other law-abiding firms. Consequently, acting as a proxy of former senior bureaucrats, princelings function as the bridge between the two interested parties, under the cover of loopholes in laws. The motives of both sides facilitate rent-seeking behaviours that take place through bribery and corruption. As a result, equipped with guaranteed government connections, princeling-backed firms are able to enjoy many direct and indirect advantages, which surely contributes to better corporate performance and development. Given this situation, it is not surprising that princeling-backed firms are considered to be favourable debtors by banks, especially state-owned banks, and that this directly results in more bank loans.

To a further extent, according to Chen (2011), firms with different ownership structures may have diverse experiences in regard to political connections. On the one hand, due to weak property right protection accompanied by a long history of discrimination against entrepreneur enterprises in China, non-SOEs are always in a 
disadvantageous position in the external financial market, and they experience stronger incentives to obtain princeling connections to turn the table. Once connected, non-SOEs are likely to receive considerable benefits. In non-SOEs, princeling connections help to remedy their inferiority (compared with naturally governmentconnected SOEs) and even to gain superiority (compared with non-princeling-backed non-SOEs). Banks, mainly state-owned banks, may find it hard to reject loan applications from princeling-backed non-SOEs due to their political backgrounds. On the other hand, since SOEs are naturally connected to the government, they have already had a taste of every possible privilege. Thus, SOEs may not experience an improvement in their situation as a result of princeling connections. Furthermore, corruption in SOEs creates the potential for collusion between government bureaucrats and SOE managers to provide personal benefits for both (Pan and Tian, 2017). The tunnelling issue in SOEs may even be aggravated by princelings, since their political backgrounds protect them from possible punishments, which does harm to princeling-backed firms. Overall, princeling-backed non-SOEs are favoured by banks compared to non-princeling-backed non-SOEs, while princeling-backed SOEs do not benefit from but even suffer from the connections. The above discussion gives rise to the following hypothesis:

H1a: Princeling connections help non-SOEs to gain more bank loans, while having negative impacts on access to bank loans in SOEs.

H1a deals with the impact of princeling connections on access to bank loans in individual firms. Nevertheless, we are more interested in how princeling connections affect bank lending decisions. It is reasonable to expect that firm profitability is one of the most essential criteria for assessing bank loan applications. Usually, firms with better profitability are more likely to receive relatively more bank loans. Based on the argument above, princeling-backed firms gain more bank loans because they are considered to be better and safer debtors by banks. Therefore, it can be further assumed that banks tend to award more loans to princeling-backed firms, due to the privileges and protections they can get from the government, without worrying too much about their profitability. The situation is different from what normally happens. In other words, if firms establish princeling connections, even if their profitability is poorer, they are able to obtain more loans which were previously unavailable. To some extent, the privileges brought by princeling connections offset the deficiency of 
poor firm profitability. Therefore, a sub-hypothesis is developed:

H1b: Bank lending to princeling-backed firms is less responsive to firm profitability than bank lending to firms that do not have princeling connections.

\subsection{Princeling connections and corporate investment}

As princeling connections are supposed to bring more bank loans, we are curious about their further influence on other aspects of corporate operations. Since external financing is one of the most common methods of raising investment capital, especially in China where other financial markets are relatively underdeveloped, it is worth investigating the relationship between additional bank loans and investment growth in princeling-backed firms. Chen et al. (2011) documented that normal political connections weaken the sensibility of investment expenditure to investment opportunities in SOEs, but have no significant influence in non-SOEs. In line with the research of Chen et al., this study explores the impacts of princeling connections on investment efficiency, expecting to reveal more details. We predict that the situations in SOEs and non-SOEs will be different for the same reason proposed earlier regarding bank loans.

On the one hand, it is relatively easier for SOEs to access bank loans due to their inherent state-owned nature. Therefore, princeling connections do not dramatically increase their access to bank loans. To a further extend, no obvious changes are expected in their investment decisions. On the other hand, in princeling-backed nonSOEs, it is reasonable to assume that the majority of additional bank loans, especially long-term bank loans, are transferred into investment expenditure. With excess financial capital, princeling-backed non-SOEs tend to invest more than they used to. Thus, investment growth should be increased by the presence of princeling connections as well. However, since princeling-backed non-SOEs are receiving more bank loans than they should, regardless of firm profitability, they are eagerly searching for more investment opportunities in addition to the optimal ones, resulting in their being less cautious when making investment decisions. Consequently, we predict that princeling-backed non-SOEs tend to overinvest as a result of their soft budgetary constraints, leading to lower investment efficiency:

H2: Princeling connections generally give rise to investment growth, and make 
investment growth less responsive to investment opportunities in non-SOEs, but do not make investment growth less responsive to investment opportunities in SOEs.

\subsection{Princeling connections and the anti-corruption campaign}

$\mathrm{H} 1$ and $\mathrm{H} 2$ are proposed based on the argument that princeling connections work by means of bribery and corruption. More specifically, in this tripartite transaction, individual firms play the role of briber, and bureaucrats play the role of bribee, while princelings act as agents between the two interested parties. Equipped with the political network built by their fathers' generation, princelings have easy access to incumbent bureaucrats who are their fathers' former colleagues and subordinate officials. Utilising such networks, princelings enable the trade-off between personal benefits for corrupted bureaucrats and privileges for bribing firms. Undoubtedly, the intermediary princelings gain their own benefits during the process. As a result, bureaucrats' willingness to exert political power and engage in corrupt activities, along with the actions of firms, facilitate the establishment of princeling connections in the first place. In summary, the improvement of corporate financing in princelingbacked firms actually depends on corruption activities. Recently, the Chinese government decided to stop the chaos, and promoted a nationwide anti-corruption campaign, and this provides us with a suitable context for examining the impact of princeling connections in a natural experiment setting. At the end of 2012, the National Congress of the Chinese Communist Party launched an 'eight-point' Antibureaucracy and Formalism Regulation, and declared the commencement of an anticorruption campaign. This was followed by very detailed implementations, and the severest-ever anti-corruption campaign has had significant influence in many respects, even at the firm level (Ke et al., 2016). During the progress of the campaign, a large number of corruption cases have been exposed, and corrupt bureaucrats were arrested in 2013 and 2014. Based on this anti-corruption activity, the impacts of princeling connections before and after the anti-corruption campaign will be compared to detect any changes. Basically, if the impacts of princeling connections do depend on corrupt activities, a sharp change is expected to be observed, given the success of the campaign. To illustrate the authenticity of this fact statistically, the influence of the anti-corruption campaign on the power of princeling connections is examined with the following hypothesis: 
H3: The impacts of princeling connections have been changed after the anticorruption campaign.

\section{Research design}

\subsection{Sample}

\subsubsection{Definition of key variables}

The most important variable in the models is Princelings. As mentioned in Section 1, 'princelings' refers to direct descendants of former senior government bureaucrats who were in provincial or higher-level positions. The Princelings variable is initially proposed in this study as a measure of this typical kind of political connection, which is differentiated from normal political connections, for its impacts have not yet been academically investigated. To avoid ambiguity, a firm is defined as princeling-backed if it satisfies both the following criteria: (1) one of its top 10 shareholders or CEO or board members (including chairman) is a direct descendant of a former senior bureaucrat; (2) the former bureaucrat was in a provincial or higherlevel position. The first criterion ensures that the sample of princeling-backed firms comprises firms with princeling shareholders and firms with princeling executives. The second criterion ensures the study accords with the reality that only senior bureaucrats are considered to remain influential after their government tenure. Ultimately, a dummy variable Princelings is generated, which equals 1 if a listed firm is defined as princeling-backed and it equals 0 otherwise.

Other than Princelings, normal political connections are also included as a control variable, and to enable a further comparison between the two types of political connections. In light of extant literature, normal political connections are said to occur when firms employ executives with governmental working experience. Precisely, a firm is considered to be politically connected if any of its CEO or board members (including chairman) is a former government official, or (current or former) deputy of the People's Congress or the People's Political Consultative Conference (Chen et al., 2011; Liu et al., 2013). Hence, the dummy variable Normal PC is generated, which equals 1 if the listed firm employs executives with working experience in the government and it equals 0 otherwise. Dependent variables include Bank loan (Total bank loan, Long-term bank loan and Short-term bank loan) and Investment growth. A 
set of selected variables were employed as control variables for other aspects of firm characteristics, including ROS, Tobin's Q, Size, Tangibility and so on. Detailed definitions and calculations of the dependent and control variables are reported in Appendix A. In avoiding abnormal observations, all the variables are trimmed at the $1 \%$ level in each tail.

\subsubsection{Data collection}

The sample of princeling-backed firms was manually collected in two ways. Firstly, on the one hand, we searched through the searching engines of Google and Baidu, as well as from the reports in the state media Xinhua News Agency and other mainstream media, for all potential princelings who were possibly involved in business and thus made a princeling list. Since those princelings usually had attracted so much attention from public and media due to their special family backgrounds and personal anecdotes, various referential information to most of the princelings could be easily accessed through the internet. Therefore, we searched every potential princeling on the list for his/her family information, education background, career and life experience. Accordingly, we archived a brief profile for each princeling. On the other hand, according to the Securities Law of the People's Republic of China and the disclosure rules of the China Securities Regulatory Commission (CSRC), IPO prospectuses of firms must contain sections on "Profile of Directors and Senior Managers", "Background of Large Shareholders", and "Background of Founding Investors". Similarly, annual reports of listed firms must provide resumes of incumbent executives, including their year of birth, educational background, and professional history. Depending on the publicly accessible information on both sides, we searched in IPO prospectuses and annual reports for executives/shareholders who shared the same name with the princelings, and then compared the resumes of executives/shareholders to the profiles of princelings. An exact match between one executive's/shareholder's resume and a princeling's profile implied that they were the same person. In other words, we were able to confirm that this firm was princelingbacked. By repeating this process, we went through the long list of princelings manually to identify princeling-backed firms.

Secondly, we searched through the official website of the Central Commission

for Discipline Inspection of the Communist Party of China for exposed corruption 
cases that involved descendants of former senior bureaucrats. Afterwards, related information was collected by utilising the searching engines of Google and Baidu, as well as reports in the state media Xinhua News Agency and other mainstream media if applicable. If any of the aforementioned information resources indicated that a firm was related to princelings, we went through its IPO prospectus and annual reports for a double check. Once all necessary information had been verified, the firm was added to the sample of princeling-backed firms.

To conclude, if an executive or/and a top-10 shareholder were recognised as a princeling by either of the two ways above, the firm he/she was serving was considered to be princeling-backed. To clarify further, because small shareholders do not have sufficient influence on corporate operations, if a princeling only held shares (not being an executive) but was not ranked in top 10 shareholders, the firm was not considered as princeling-backed frim. We admit, due to the limitation of information disclosure in China, we are unable to have a complete princeling data set. Nevertheless, we believe that the sample of princeling-backed firms collected from two sources in this study is validly representative for the princeling-backed firm population. If the estimated results from the limited data set of princeling-backed firms are significant and have explanation power, the estimated results from the whole population of princeling-backed firms would have more explanation power.

With respect to the process of basic data collection, we firstly include all the qualified firms listed on the Shanghai and Shenzhen stock exchanges (SHSE and SZSE) from 2004 to 2014, excluding the Small and Medium Sized Enterprise board (SEM) and Growth Enterprise Market board (GEM). In order to eliminate abnormal observations, listed firms in the financial sector are excluded due to their unique accounting standard and special capital structures, as well as firms with Special Treatment (ST) and Particular Transfer (PT) status according to usual data processing methods. Most of the data is collected from multiple sub-databases in the China Stock Market and Accounting Research Database (CSMAR). All the financial information and indexes are collected from the Chinese Listed Firm Annual Report Database and Chinese Listed Firm Financial Variables Analysis Database. In addition, the Chinese Listed Firm Corporate Governance Database and the Chinese Listed Firm Shareholder Analysis Database are used to collect background information about firm shareholders and executives. In total, we have 19440 firm year observations. 


\subsubsection{Sample distribution and summary statistics}

Table 1 reports on the sample distribution of princeling-backed listed firms. Panel A shows the distribution by year and ownership structure. On average, 7.63\% SOEs and $7.90 \%$ non-SOEs were princeling-backed. There was an obvious drop in numbers of princeling-backed firms after the anti-corruption campaign at the end of 2012. According to Panel B, the sample distribution by industry, princeling-backed firms were apparently concentrated in several industries. The highest densities of princeling-backed firms were spotted in the mining, transportation and business service industries, followed by the resources, real estate and utilities industries. This distribution supports our argument that princeling connections exert an influence by participating in the sectors with high levels of government intervention, for instance the real estate and utilities industries. In addition, princeling-backed firms in the business services and utilities industries provide circumstantial evidence that princelings have shortcuts to insider information and privileges in winning government contracts.

Insert Table 1 here

Table 2 reports summary statistics of all variables included in our regression models and univariate test results of dependent variables between princeling-backed and non-princeling-backed firms. According to Panel B, princeling-backed firms received significantly more bank loans compared to non-princeling-backed firms, including long-term and short-term bank loans. Simultaneously, princeling-backed firms experienced higher growth rates in investment. All the univariate tests results are preliminarily consistent with our hypotheses.

Insert Table 2 here

\subsection{Regression models}

As proposed in Section 2 regarding the hypotheses, this paper mainly explores the impacts of princeling connections on corporate external financing, bank lending decisions, and corporate investment decisions, as well as the influence of the anticorruption campaign on princeling connections. Hence, a set of regression models is developed as follows. In order to investigate the primary hypothesis regarding corporate bank loans, the first regression model is established in the light of Liu et al. 
(2016).

$$
\begin{aligned}
{\text { Bank } \text { loan }_{i t}=} & \beta_{0}+\beta_{1} \text { Princelings }_{i t}+\beta_{2} \text { Princelings }_{i t} \times S O E_{i t}+\beta_{3} \text { SOE }_{i t} \\
& +\beta_{4} \text { Normal PC }_{i t}+\beta_{5} \text { ROS }_{i t-1}+\beta_{6} \text { Tobin's }_{i t-1}+\beta_{7} \text { Size }_{i t} \\
& +\beta_{8} \text { Tangibility }_{i t}+\beta_{9} \text { Board }_{i t}+\beta_{10} \text { Independence }_{i t}+\varepsilon_{i t}
\end{aligned}
$$

where the dependent variable Bank loan is the level of access to bank loans, including total bank loans, long-term bank loans and short-term bank loans. The variable Princelings is an essential dummy, which equals 1 if a firm is recognised as princeling-backed and equals 0 otherwise. SOE is a dummy that equals 1 for SOEs and 0 for non-SOEs. The interaction term between Princelings and SOE shows the diverse impacts of princeling connections on firms with different ownership structures. Normal PC is a dummy variable that equals 1 when a firm is politically connected by executives with government working experience and it equals 0 otherwise. ROS (return on sales) stands for firm profitability, and Tobin's $Q$ represents investment opportunity. Two groups of indicators that control for the financial and corporate governance characteristics of different firms are included. The former includes Size (natural logarithm of total assets) and Tangibility. The latter includes Board (natural logarithm of board size) and Independence (percentage of board independence), please see Appendix A. Year and Industry dummy variables are also included to control for year and industry fixed effects.

The coefficient of Princelings, $\beta_{1}$, is expected to be significantly positive, supporting the hypothesis that princelings generally improve the access to bank loans in firms. According to $\mathrm{H} 1 \mathrm{a}$, the coefficient of the interaction term, $\beta_{2}$, is expected to be significantly negative, suggesting princeling connections bring relatively more bank loans to non-SOEs compared to SOEs. In addition, the coefficient of $S O E, \beta_{3}$, is expected to be significantly positive, reflecting the fact that SOEs normally receive more bank loans than non-SOEs because of their nature connections to the government.

In order to test H1b regarding bank lending decisions, regression (2) is constructed on the basis of regression (1). ROS is a measurement of firm profitability, which is considered to be a common criterion adopted by banks when making lending decisions. In most cases, a firm with high profitability is likely to get more bank loans because of its better debt repayment ability. Therefore, the interaction term between 
Princelings and ROS reveals whether princeling connections distort this decisionmaking rule.

$$
\begin{aligned}
\text { Total loan ratio }_{i t}= & \beta_{0}+\beta_{1} \text { Princelings }_{i t}+\beta_{2} \text { Princelings }_{i t} \times \text { ROS }_{i t-1} \\
& +\beta_{3} \text { ROS }_{i t-1}+\beta_{4} \text { Normal PC }_{i t}+\beta_{5} \text { Tobin's }_{i t-1} \\
& +\beta_{6} \text { Size }_{i t}+\beta_{7} \text { Tangibility }_{i t}+\beta_{8} \text { Board }_{i t} \\
& +\beta_{9} \text { Independence }_{i t}+\varepsilon_{i t}
\end{aligned}
$$

where all the variables are defined in the same way as in regression (1). The coefficient of $R O S, \beta_{3}$, is expected to be significantly positive which indicates the fact that firm profitability is usually positively correlated with access to bank loans in individual firms. More importantly, the coefficient of the interaction term between Princelings and $R O S, \beta_{2}$, is expected to be significantly negative to provide evidence to support H1b that princeling connections distort the profitability criterion of bank lending decisions.

Furthermore, regression (3) is structured to examine H2. Following Chen (2011), the dependent variable is investment growth, while Tobin's $Q$ represents investment opportunity. Similar to regression (2), normally, investment growth is positively responsive to investment opportunities, reflecting healthy investment efficiency. Thus, the interaction term between Princelings and Tobin's $Q$ indicates whether princeling connections have any influence on investment efficiency.

$$
\begin{aligned}
\operatorname{Ln}\left(\frac{I_{i t}}{I_{i t-1}}\right)= & \beta_{0}+\beta_{1} \text { Princelings }_{i t}+\beta_{2} \text { Princeling }_{i t} \times \text { Tobin's }_{i t-1} \\
& +\beta_{3} \text { Tobin's }_{i t-1}+\beta_{4} \text { Normal PC }_{i t}+\beta_{5} \text { Leverage }_{i t-1} \\
& +\beta_{6} \text { Size }_{i t}+\beta_{7} \text { Tangibility }_{i t}+\varepsilon_{i t}
\end{aligned}
$$

The coefficient of Tobin's $Q, \beta_{3}$, is expected to be significantly positive, showing the normal relationship between investment opportunities and growth. Meanwhile, the coefficient of Princelings, $\beta_{1}$, is expected to be significantly positive as well, which indicates princeling connections promote investment growth due to the extra bank loans brought by them. However, the coefficient of the interaction term between Princelings and Tobin's $Q$ is expected to be significantly negative to show that princeling connections indirectly do harm to investment efficiency. 
Finally, to test $\mathrm{H} 3$ on the influence of the anti-corruption campaign, regression (4) and (5) are developed as follows to give separate results on bank lending decisions and corporate investment decisions. The control variables are also different for different tests. The whole sample is firstly divided in to two subsamples for SOEs and non-SOEs, and each subsample is further divided into two parts to indicate princelingbacked and non-princeling-backed firms respectively.

$$
\begin{gathered}
\text { Total loan ratio } \text { it }=\beta_{0}+\beta_{1} \text { Campaign }+\beta_{2} \text { Campaign } \times \text { ROS }_{i t-1}+\beta_{3} \text { ROS }_{i t-1} \\
+\beta_{i} \text { Controls }_{i t}+\varepsilon_{i t} \\
\begin{aligned}
\text { Ln }\left(\frac{I_{i t}}{I_{i t-1}}\right)= & \beta_{0}+\beta_{1} \text { Campaign }+\beta_{2} \text { Campaign } \times \text { Tobin's }^{\prime} Q_{i t-1}+\beta_{3} \text { Tobin }^{\prime} \text { S }_{i t-1} \\
& +\beta_{i} \text { Controls }_{i t}+\varepsilon_{i t}
\end{aligned}
\end{gathered}
$$

In regression (4), the coefficient of the interaction term between Campaign and $R O S$ is expected to be significantly positive in princeling-backed firms, suggesting the importance of firm profitability has been reinforced and that bank lending decisions have returned to normal due to the anti-corruption campaign. Similarly, in regression (5), the coefficient of the interaction term between Campaign and Tobin's $Q$ is expected to be significantly positive in princeling-backed firms as well, reflecting that the prediction that the campaign has restored the healthy relationship between investment opportunities and growth, and that the campaign has eliminated the crowding out effect previously caused by princeling connections.

\section{Empirical results and analysis}

\subsection{Impact of princeling connections on firm's ability to access bank loans}

To test the primary hypothesis regarding the relationship between princeling connections and level of access to corporate bank loans, regression (1) was run for empirical evidence. Table 3 reports the impact of princeling connections on access to total bank loans, long-term bank loans and short-term bank loans respectively. The results of a basic regression without the dummy variable SOE are shown in columns 1, 3 and 5. The coefficients of Princelings are all positively significant at the $1 \%$ level, which indicates princeling connections generally improve the access to all types of bank loans. 
Insert Table 3 here

Based on the reasoning described above, the dummy variable $S O E$ was introduced to examine the individual impact of princeling connections in firms with different ownership structures. The detailed empirical results are shown in columns 2, 4 and 6. Again, the coefficients of Princelings are positive and significant at the $1 \%$ level, providing extra evidence that princeling connections ensure better access to bank loans. Given the circumstance that the largest banks in China are all controlled by the government, there have always been privileges for princeling-backed firms which have enabled them to obtain more bank loans than other firms. Furthermore, the coefficients of the dummy variable SOE are all positively significant at the $1 \%$ level, suggesting that SOEs normally receive significantly more bank loans than nonSOEs due to their inherited connections to the government. More importantly, the coefficients of the interaction term between Princelings and SOE are significantly negative at the $1 \%$ level in column 2 and 4 . Considered together with the coefficients of Princelings, the interaction term coefficients indicate that princeling connections help non-SOEs to gain significantly more bank loans, especially more long-term bank loans than non-princeling-backed non-SOEs, but have significantly negative impacts on access to bank loans in SOEs, which is consistent with H1a. However, the interaction term coefficient in column 6 is negative but not statistically significant, which suggests that the difference between the impacts of princeling connections on access to short-term bank loans in SOEs and non-SOEs is not significant. It is not surprising that princeling connections do not bring extra bank loans to SOEs, because the nature governmental connections of SOEs have basically the same effects as princeling connections and are even stronger in many cases. Furthermore, it is to be expected that the impacts of princeling connections on access to bank loans are negative in SOEs due to the collusion between corrupt bureaucrats and princelings and tunnelling issue. On the contrary, the situation in non-SOEs is just the opposite. Due to the institutional background of poor property rights protection and a long history of discrimination against privately-owned enterprises, princeling-backed nonSOEs experience dramatic boosts in their access to bank loans. Due to their governmental connections and protections, princeling-backed non-SOEs allay the concerns of banks, and are therefore at the same level as SOEs when competing for loans. 
Another important variable, Normal $P C$, is included in the regression as a comparable term, as well as a control variable for Princelings. The impact of normal political connections on access to bank loans has already been demonstrated in the literature (Berkmanet et al., 2009; Blau et al., 2013; Yeh et al., 2013). The coefficients of Normal PC in every column are all positively significant, illustrating the bankloan-winning nature of normal political connections. Nevertheless, at the same $1 \%$ significance level, the coefficients of Princelings are always much larger than those of Normal PC, indicating that the power of princeling connections are much greater than the power of normal political connections. The two types of political connections work towards the same outcome which may even have a synergistic effect. The relationship between princeling connections and normal political connections will be further discussed in Section 4.5.2. The inclusion of Normal PC further proves that, after controlling for the positive effect of normal political connections, princeling connections still have additional power over access to bank loans. In addition to Normal PC, other control variables all take the expected signs. In particular, as one of the most essential criteria of bank lending decisions, $R O S$ is included for further analysis. The coefficients of ROS are significantly positive at the $1 \%$ level, demonstrating the positive relationship between bank lending and firm profitability.

In summary, non-SOEs have the incentive to establish princeling connections since princeling connections do improve their financing performance. Such incentives are actually stimulated by the plights of non-SOEs when they are competing with SOEs. Princeling connections strengthen the competitive power of non-SOEs. Nevertheless, it could be argued that the superior performance of princeling-backed non-SOEs comes at the cost of an even harsher situation for non-princeling-backed non-SOEs. The allocation of limited external financial resources to overall non-SOEs now favours princeling-backed non-SOEs, and this gradually crowds out the living space for non-princeling-backed non-SOEs and finally does harm to the general economy. The Chinese government launched the severest ever anti-corruption campaign which has effectively cut off corruption by princeling connections. Detailed empirical results will be discussed in Section 4.4.

\subsection{Impact of princeling connections on bank lending decisions}


In Section 4.1, it is demonstrated that princeling connections do provide firms with better access to bank loans. Therefore, since banks always have a set of criteria to follow while making lending decisions, how do princeling connections change bank loan approval standards? Based on the discussion in Section 2.1, we suggest that this change is related to firm profitability. Firm profitability is considered to be a solid indicator for bank loan repayment. If a firm does not show satisfactory profitability, it is rational to assume that it would not have enough capital to repay its debts. This confirms the importance of firm profitability in bank lending decisions. According to Zheng and Zhu (2013), when loans are awarded to firms with high profitability, this is a good bank lending decision. Therefore, in normal cases, bank lending should be highly responsive to firm profitability, represented by the relationship between Total bank loan and ROS in regression (2). To find out the answer to the question of how princeling connections affect bank lending decisions, regression (2) was run to test H1b which predicts that princeling connections weaken the role of profitability in determining the outcomes of loan applications. Table 4 reports on the impact of princeling connections on bank lending decisions.

Insert Table 4 here

In Table 4, the coefficients of Princelings are significantly positive at the $1 \%$ level, regardless of different firm ownership structures, confirming the result in Section 4.1 that princeling-backed firms do receive more bank loans. The coefficients of $R O S$ are also significantly positive, suggesting that bank lending is normally highly responsive to firm profitability. However, the coefficient of the interaction term between Princelings and ROS is significantly negative at the 5\% level in column 1 for the whole sample, which indicates that princelings connections generally weaken the positive relationship between bank lending and firm profitability. To be specific, the level of access to bank loans of a firm is normally positively related with its profitability, as demonstrated by the statistically significant and positive coefficients of ROS. However, according to the results, such relationship is weakened in princeling-backed firms, which reveals banks value princeling connections more than firm's profitability. In other words, when a firm is princeling-backed, banks are willing to lend more loans even if the firm is not eligible for the extra loans if judged by its profitability. Upon the fact that firm profitability is one of the key factors of bank loans approval, the significantly negative coefficient shows princeling 
connections make bank lending less responsive to firm profitability. This result suggests that, to some extent, princeling connections help firms to win bank loans in a way of distorting bank lending decisions. In columns 2 and 3, the coefficients of the interaction term are significantly negative at the $1 \%$ and $5 \%$ levels, leading to the same conclusion that princeling connections make bank lending decisions less responsive to firm profitability. More specifically, the coefficient in column 2 for SOEs is larger in magnitude than in column 3 for non-SOEs (-0.234 vs. -0.025$)$, and the coefficient in column 2 is more significant than the coefficient in column 3 (the $1 \%$ level compared to the $5 \%$ level). We also conduct the Chow test to examine the difference between the coefficients of the interaction term for SOEs and non-SOEs, and the result shows that the impact of princeling connections on bank lending decisions is stronger for SOEs. This result reflects the difference between the two ownership structures. Princeling connections in SOEs reinforce the power of their natural governmental connections, which makes princeling-backed SOEs the most reliable debtors regardless of their profitability. Overall, the empirical results are consistent with H1b.

\subsection{Impact of princeling connections on corporate investment decisions}

According to the analysis in Sections 4.1 on Table 3, princeling connections help both SOEs and non-SOEs to gain more bank loans of all types. Moreover, princelingbacked non-SOEs receive significantly more long-term bank loans than princelingbacked SOEs. To a further extent, since external financing capital is always the main source of investment expenditure, we are more interested in how the increase in longterm bank loans affects corporate investment decisions.

Table 5 reports the impact of princeling connections on investment activity in the whole sample, as well as in SOEs and non-SOEs separately. The results can be analysed from two perspectives, investment expenditure and investment efficiency. First of all, it is clear that the coefficients of Princelings are significantly positively at the 5\% level in columns 1 and 3 , indicating princeling connections promote investment growth mainly in non-SOEs. This result is consistent with the discussion in Section 4.1. The dramatic increase in access to long-term bank loans consequently boosts investment growth in princeling-backed non-SOEs. Secondly, with respect to 
investment efficiency, the relationship between investment growth and Tobin's Q is considered to be a proxy. In details, the significantly positive coefficients of Tobin's $Q$, representing investment opportunities, suggest that investment growth is normally highly responsive to investment opportunities. Investment decisions are rational if increased investment growth is backed up by more investment opportunities. Again, the coefficients of the interaction term between Princelings and Tobin's $Q$ are what we are most interested in. The coefficient of the interaction term is negative and statistically significant at the $1 \%$ level in columns 1 , revealing that princelings connections generally weaken the positive relationship between investment growth and investment opportunities. Specifically, while the significantly positive coefficients of Tobin's $Q$ suggest that investment growth is positively related with investment opportunities (Tobin's Qs), this relationship is significantly weakened in princeling-backed firms. This result suggests that, with excess loans, princelingbacked firms no longer consider investment opportunities as much as they should (compared to non-princeling-backed firms). Thus, princeling-backed firms are likely to extend their investment to sub-optimal opportunities instead of investing in optimal opportunities only, which results in lower investment efficiency than non-princelingbacked firms. Moreover, the coefficient in column 3 is negative and statistically significant at the $1 \%$ level and is larger in magnitude compare to the all sample coefficient in column 1 . This result suggests that in princeling-backed non-SOEs, investment growth becomes less responsive to investment opportunities, resulting in lower investment efficiency. Comparatively, the results in column 2 show that the impacts of princeling connections on investment decisions in SOEs is not significant which are consistent with $\mathrm{H} 2$.

Insert Table 5 here

\subsection{The influence of the anti-corruption campaign on princeling connections}

As discussed in previous sections, the benefits brought by princeling connections are at the cost of non-princeling-backed firms. In a financial market with limited capital resources, princeling-backed firms are crowding out non-princeling-backed firms, which is harmful to the sustainable development of the Chinese economy. Being aware of the severity of this corruption-related issue, the Chinese government has taken actions to make up for the loopholes in laws, among which the anti- 
corruption campaign is the most representative activity. Table 6 shows the impact of the anti-corruption campaign on princeling connections regarding bank lending decisions. Campaign is a time dummy variable adopting a breakpoint at the end of year 2012, because the anti-corruption campaign began at this time. In order to investigate the influence of the campaign, an interaction term between Campaign and ROS is generated. Consistent with the method employed in former tests, the whole sample is divided into two subsamples - SOEs and non-SOEs. Furthermore, to avoid cubic terms, Princelings is taken out of the original regression and used to divide the subsamples into smaller groups. More specifically, both SOEs and non-SOEs are further divided into princeling-backed and non-princeling-backed firms.

Insert Table 6 here

Based on the discussion in Section 4.2, princeling connections have a major impact by weakening the relationship between level of access to bank loans and firm profitability. Therefore, according to Table 6, the significantly positive coefficients of the interaction term in columns 1 and 3 suggest that the relationship between Total bank loan and ROS has been reinforced in princeling-backed SOEs and non-SOEs by the campaign. Since various corruption activities, including collusion between business owners and government bureaucrats have been curtailed by the campaign, princeling-backed firms are no longer able to earn extra bank loans utilising such connections. Consequently, bank loans are reallocated, leading to a recovery in the level of access to loans in non-princeling-backed firms, which is demonstrated by the significantly positive coefficients of Campaign in columns 2 and 4. The results are consistent with H3.

At the meantime, Table 7 reports the impact of the anti-corruption campaign on the relationship between princeling connections and investment decisions. Similarly, the key interaction term between Campaign and Tobin's $Q$ is included, and the whole sample is divided into four subsamples. The significantly positive coefficients of the interaction term in columns 1 and 3 show that in princeling-backed firms the positive relationship between investment growth and Tobin's Q was restored after the campaign. It can be concluded that the impact of princeling connections on investment decisions has been weakened by the campaign, providing additional empirical evidence for $\mathrm{H} 3$. 


\subsection{Additional analysis}

\subsubsection{Heterogeneity of princeling connections}

This study expects to gain an insight into the heterogeneity of princelings regarding their different roles in firms. To be more specific, in the light of agency theory, we intend to further investigate the impacts of princeling connections from the perspective of conflicts between principals and agents. Hence, princeling executives are placed in an "agent" subsample, and princelings who are controlling shareholders are placed in a 'principal' subsample. Princelings who are controlling shareholders were initially included in this study for their undoubtedly important role in corporate operations. According to the Company Law of the People's Republic of China, general meetings of shareholders are in charge of decision-making, including investment plans and management policy. Necessarily, based on the one-share-onevote rule, the impact of princelings who are controlling shareholders should also be examined to provide a comprehensive analysis of the heterogeneity of princeling connections.

Table 8 shows a comparison between princeling shareholders and princeling executives regarding the impact of princeling connections on access to bank loans. The whole sample is firstly divided into two sub-samples based on different ownership structures, and each sub-sample is further divided into two smaller subsamples representing princeling shareholders and princeling executives. According to Princelings in the first row, the coefficients of princeling executives (in columns 2, 4 and 6) are much larger than those of princeling shareholders (in columns 1, 3 and 5). The results suggest that princeling executives have much stronger loan-earning capacities compared to princeling shareholders, even though they both significantly improve access to total bank loans.

Insert Table 8 here

Similarly, Table 9 and 10 show the comparison between princeling shareholders and princeling executives regarding their impacts on bank lending decisions and corporate investment decisions. Referring to the coefficients of Princelings in Table 9, the results are consistent with those in Table 8. Furthermore, it is quite clear that the significantly negative coefficients of the interaction term in columns 2, 4 and 6 reveal that princeling executives significantly distort the relationship between bank lending 
and ROS. However, princeling shareholders do not share the same effect, while none of the coefficients in columns 1, 3 and 5 are significant. Therefore, the conclusion is that princeling executives have a stronger impact on bank lending decisions. Table 10 shows a similar situation where princeling executives have much stronger impacts on reducing investment efficiency. The comparison between the two types of princelings gives us a deeper insight into their characteristics. It is clear that princeling executives play a much more important role. The reason may be traced to agency theory. As principals, if princeling shareholders decide to pursue certain goal utilising their political power, they are more likely to suffer from conflict between principals and agents due to their different roles. However, princeling executives are normally free of such troubles for they are directly responsible for corporate management and operations. Additionally, it is possible that princeling shareholders tend to keep their political backgrounds under cover and somehow pursue their goals secretly.

Insert Table 9 here

Insert Table 10 here

\subsubsection{Princeling connections and normal political connections}

Princeling connections are introduced in this paper as a new perspective on political connections. Therefore, normal political connections should be included in the analysis as well to enable a comprehensive conclusion. In particular, the interacting relationship between the two types of political connections is worth exploring. Tables11and 12 give a comparison between the impacts of princeling connections in firms with and without normal political connections. Specifically, columns 1 and 3 show the situation when princelings and normal political connections co-exist, while columns 2 and 4 include firms with princeling connections only.

\section{Insert Table 11 here}

Insert Table 12 here

The extant literature demonstrates that normal political connections do improve access to bank loans. Given that, the significantly positive coefficients of Princelings in Table 11, especially in columns1 and 3, suggest that princeling connections help to gain more bank loans over and above the impact of normal political connections. In other words, even though the two political connections have the same impact on access to bank loans, they both make their individual contributions. The impact of 
princeling connections is not obscured by the impact of normal political connections, and there may even be a synergistic effect between them. However, the coefficients of the interaction term are statistically significant and negative in columns 2 and 4, indicating that the distortion of bank lending decisions by princeling connections is only observed in firms without normal political connections. In Table 12, the impact of princeling connections on investment decisions is observed in non-SOEs only, which is consistent with the discussion in Section 4.3. The coefficients of the interaction term between Princelings and Tobin's $Q$ are statistically significant and negative in columns 3 and 4 at the $10 \%$ and $1 \%$ levels respectively (-0.141 vs. -0.152$)$, indicating that the impact of princeling connections on investment decisions is much stronger in non-SOEs without normal political connections.

\subsection{Robustness results}

\subsubsection{Potential endogeneity issue}

In this section, the potential endogeneity issue in our regression models is addressed. The most possible cause of the issue is that princeling connections are not entirely exogenous in the regression models. More specifically, since the regression models adopt many indexes that represent different aspects of corporate operations, it is difficult to tell if princeling connections have no correlation whatsoever with any of them. For instance, regarding profitability, one could argue that some firms are princeling-backed because they are generous employers due to their good corporate performance. Otherwise, it could be argued that princelings are willing to take positions in a firm due to its excellent corporate performance and operation. As a result, princeling connections could be endogenous if correlated with profitability, which gives rise to a potential endogeneity problem.

In order to solve the potential endogeneity of princelings connections, difference in difference (DiD) method is adopted. As mentioned in section 2.3, the anticorruption campaign can be considered as an appropriate event for a natural experiment to be used in the DiD method. In section 4.4, the influence of the anticorruption campaign on the impacts of princeling connections is briefly analysed in pooled regressions. In this section, random effect model is applied to test the robustness of the results of the impacts of princeling connections on access to bank 
loans and investment growth by utilizing the influence of the campaign. Fixed effect model is not a proper way to solve the endogeneity issue in this study, because the value of the dummy variable Princelings changes in different firms so that the term Princelings will be omitted in fixed effect regression results. Following the DiD method, princeling-backed firms are considered as the treated group, while others as the control group. The anti-corruption campaign is the shock that naturally divide the whole sample period into two parts. Based on the empirical results that a princelingbacked firm have better access to bank loans and have higher investment growth if compared with non-princeling-backed firms, and the campaign weakens the impacts of princeling connections, such difference between the two types of firms is supposed to reduce after the campaign.

Table 13 reports the DiD regression results of the random effect models. In this model, the robustness of the results that princeling-backed firms have better access to bank loans and increase investment growth is examined. According to Panel A in Table 13, the coefficients of Princelings are positive and statistically significant at the $1 \%$ level, which is consistent with the previous results that princeling connections help to improve the level of access to bank loans. We are more concerned about the coefficients of the interaction term between Princelings and Campaign. The coefficient in column 1 is significantly negative at the $5 \%$ level. Considered together with the coefficient of Princelings, the interaction term coefficient in column 1 indicates that the positive impact of princeling connections on access to bank loans is changed to negative impact after the anti-corruption campaign. This result reflects the fact that princeling-backed firms, especially non-SOEs, experienced a hard time after the campaign due to the stringent regulations on princelings and incumbent bureaucrats. The sharp reduction of corrupt activities broke the channel through which princeling connections work. The coefficients of the interaction term in columns 2 and 3 are both negative. Moreover, the coefficient in column 3 for non-SOE s is more significant (the $1 \%$ level compared to the $10 \%$ level) and is larger in magnitude than the coefficient in column 2 for SOEs. We also conduct the Chow test to examine the difference between the interaction term coefficients for SOEs and non-SOEs. Considered together with the coefficients of Princelings, the interaction term coefficients in columns 2 and 3 suggest that, after the campaign, the negative impact of princelings connections on access to bank loans is more severe in non-SOEs. Since 
princeling-backed non-SOEs benefited more than princeling-backed SOEs, they are more affected by the anti-corruption campaign.

Panel B in Table 13 shows the difference in difference random effect model regression results of the impacts of princelings connections on investment growth. Similarly, we are most interest in the coefficients of the interaction term between Princelings and Campaign. The coefficients are all negative in three columns. Most importantly, the coefficient in column 3 for non-SOE s is more significant (the $5 \%$ level compared to the $10 \%$ level) and is larger in magnitude than the coefficient in column 2 for SOEs, which is consistent with the Chow test result. Considered together with the coefficients of Princelings, the interaction term coefficients suggest that, after the campaign, the previously positive impact of princelings connections on investment growth is changed to negative impact, and the negative impact is more severe in non-SOEs. The reason is that princeling connections are no longer helpful and princelings are under stringent regulations after the campaign, which has a negative influence on princeling-backed firms, especially non-SOEs.

Insert Table 13 here

\subsubsection{Other robustness tests}

Other than employing the instrumental variable, alternative measurements of dependent variables are adopted to give more evidence on the robustness of the fundamental models. Panel A in Table 14 shows the impact of princeling connections on change in total accessible bank loans, change in accessible long-term bank loans and change in accessible short-term bank loans, as a replacement for the originally used level of access to bank loans. The significantly positive coefficients of Princelings suggest that the conclusion about its positive impacts on access to bank loans is robust. Nevertheless, the positive impact is stronger for changes in short-term bank loans, while it is not significant for changes in long-term bank loans. Meanwhile, the significantly negative coefficients of the interaction term indicate that princeling connections guarantee more bank loans in non-SOEs, which is consistent with the discussion in Section 4.1. More specifically, the impact is also stronger on changes in short-term bank loans compared to changes in long-term bank loans.

Insert Table 14 here 
We further test robustness of regression (2) regarding bank lending decisions, using change in accessible total bank loans to replace the access to total bank loans. According to Panel B in Table 14, the coefficients of Princelings are significant and take the same sign as their corresponding coefficients in Table 4, while the coefficients of the interactions term in columns 1 and 3 are significantly negative, indicating the robustness of the conclusion that princeling connections help to gain more bank loans by distorting bank lending decisions in non-SOEs.

Finally, Panel C in Table 14 shows the impact of princeling connections on changes in investment expenditure as a replacement for investment growth. The most important term is the interaction between Princelings and Tobin's Q. The coefficients are significantly negative at the 5\% level in columns 1 and 3 , demonstrating that princeling connections make change in investment expenditure less responsive to investment opportunities, especially in non-SOEs. The results provide evidence of the robustness of the discussion in Section 4.3.

\section{Conclusions}

This paper investigates another type of political connection in addition to normal political connections. Specifically, princeling connections are proposed as a new, separate form of political connection in the Chinese market due to their significant influence. We are interested in the role of princeling connections as a complement to normal political connections in corporate operations. Based on the hypotheses in Section 2, four regression models are developed and run, using the data of Chinese listed firms from 2004 to 2015. The impacts of princeling connections on different dimensions, including corporate financing, investment activities and bank lending decisions are analysed to generate a report on the situation of princeling-backed firms.

Empirical results suggest that princeling connections generally ensure firms, especially non-SOEs, are given better access to all types of bank loans. Banks prefer princeling-backed non-SOEs due to the privileges and protections they can obtain from the government, which makes them safer debtors compared to non-princelingbacked non-SOEs. Correspondingly, bank lending becomes less responsive to firm profitability in princeling-backed firms because banks are considering the favourable connections of a firm rather than just its profitability when lending decisions are made. 
Furthermore, a liberal supply of bank loans, especially long-term bank loans, ultimately results in overinvesting by princeling-backed non-SOEs. In details, overinvesting makes investment expenditure and growth less responsive to investment opportunities, which results in lower investment efficiency. However, any privileges enjoyed by princeling-backed firms are at the cost of non-princeling-backed firms, so that they are faced with an even hasher financing environment. Fortunately, the Chinese government took immediate actions, of which its anti-corruption campaign was the most representative, to create a fairer and healthier economic environment. It has been demonstrated in this paper that the impacts of princeling connections have been significantly changed after the anti-corruption campaign. In addition, tests on the heterogeneity of princelings show that princeling executives play a more important role in firms than princeling shareholders. When it comes to the co-existence of the two different types of political connections, it is documented that princeling connections are able to further improve the access to bank loans of firms with normal political connections, which means the two types of connections may have a synergistic effect on corporate financing. As mentioned in the data collection process, we admit that we do not have a complete princeling data set due to the limitation of information disclosure in China. However, despite of possible missing observations, our empirical results are statistically significant, which suggests that our findings should remain for the population of princeling-backed firms.

In conclusion, princeling connections are a double-edged sword, and princelingbacked firms have their gains and losses. Nevertheless, princeling connections are closely related with corruption, or in other words trade-offs between money and power. Therefore, the collapse of princeling connections after the anti-corruption campaign has had a positive impact on the Chinese market. 


\section{Empirical results}

Table 1. Sample distribution

Panel A: Distribution by year and ownership structure

\begin{tabular}{|c|c|c|c|c|c|c|}
\hline \multirow[t]{2}{*}{ Year } & \multicolumn{3}{|l|}{ SOEs } & \multicolumn{3}{|c|}{ Non-SOEs } \\
\hline & $\begin{array}{l}\text { No. of } \\
\text { sample }\end{array}$ & $\begin{array}{l}\text { No. of } \\
\text { connected }\end{array}$ & $\begin{array}{l}\% \text { of } \\
\text { connected }\end{array}$ & $\begin{array}{l}\text { No. of } \\
\text { sample }\end{array}$ & $\begin{array}{l}\text { No. of } \\
\text { connected }\end{array}$ & $\begin{array}{l}\% \text { of } \\
\text { connected }\end{array}$ \\
\hline 2004 & 957 & 79 & 8.25 & 296 & 36 & 12.1 \\
\hline 2005 & 963 & 92 & 9.55 & 382 & 42 & 10.9 \\
\hline 2006 & 947 & 86 & 9.08 & 395 & 37 & 9.36 \\
\hline 2007 & 943 & 79 & 8.37 & 476 & 49 & 10.2 \\
\hline 2008 & 950 & 82 & 8.63 & 571 & 47 & 8.23 \\
\hline 2009 & 959 & 63 & 6.56 & 616 & 52 & 8.44 \\
\hline 2010 & 975 & 71 & 7.28 & 747 & 59 & 7.89 \\
\hline 2011 & 1012 & 70 & 6.91 & 1059 & 80 & 7.55 \\
\hline 2012 & 1007 & 75 & 7.44 & 1294 & 91 & 7.03 \\
\hline 2013 & 1022 & 65 & 6.36 & 1407 & 95 & 6.75 \\
\hline 2014 & 1017 & 59 & 5.80 & 1445 & 99 & 6.85 \\
\hline Total & 10752 & 821 & 7.63 & 8688 & 687 & 7.90 \\
\hline
\end{tabular}

Panel B: Distribution by industry

\begin{tabular}{llll}
\hline Industry & $\begin{array}{l}\text { No. of } \\
\text { sample }\end{array}$ & $\begin{array}{l}\text { No. of } \\
\text { connected }\end{array}$ & $\begin{array}{l}\text { \% of } \\
\text { connected }\end{array}$ \\
\hline Agriculture & 216 & 6 & 2.77 \\
Mining & 666 & 118 & 17.7 \\
Manufacturing & 12161 & 744 & 6.11 \\
Electricity, gas and water & 873 & 116 & 13.2 \\
Construction & 513 & 6 & 1.16 \\
Wholesale and retail & 1198 & 48 & 4.00 \\
Transportation & 918 & 144 & 15.6 \\
Information technology & 695 & 55 & 7.91 \\
Real estate & 1134 & 152 & 13.4 \\
Leasing and business services & 261 & 50 & 19.1 \\
Utilities & 207 & 30 & 14.4 \\
Service & 146 & 11 & 7.53 \\
Conglomerate & 452 & 28 & 6.19 \\
Total & 19440 & 1508 & 7.75 \\
\hline
\end{tabular}

This table shows sample distribution by year and ownership structure, as well as by industry. 
Table 2. Summary statistics and univariate test of key variables

Panel A: Summary statistics

\begin{tabular}{lllllc}
\hline & Mean & Median & 25th quartile & $\begin{array}{l}\text { 75th } \\
\text { quartile }\end{array}$ & StD \\
\hline Total bank loan (\%) & 15.9 & 12.9 & 5.00 & 29.61 & 17.7 \\
Long-term bank loan (\%) & 6.18 & 3.81 & 0.00 & 9.10 & 7.23 \\
Short-term bank loan (\%) & 7.25 & 2.00 & 0.00 & 11.10 & 1.72 \\
Investment growth & 0.09 & 0.15 & -0.56 & 0.75 & 1.21 \\
Tobin's Q & 1.91 & 1.42 & 0.79 & 2.41 & 1.69 \\
ROS (\%) & 3.07 & 3.06 & 0.02 & 9.13 & 1.20 \\
Leverage (\%) & 0.47 & 0.47 & 0.29 & 0.62 & 0.24 \\
Ln(Size) & 21.62 & 21.47 & 20.75 & 22.31 & 1.26 \\
Tangibility (\%) & 24.90 & 21.46 & 11.00 & 35.86 & 7.75 \\
Board & 9.02 & 9 & 8 & 9 & 1.86 \\
Independence (\%) & 35.45 & 33.33 & 33.33 & 33.33 & 6.45 \\
Princelings & 0.07 & 0.00 & 0.00 & 0.00 & 0.22 \\
Normal PC & 0.29 & 0.00 & 0.00 & 1.00 & 0.45 \\
\hline
\end{tabular}

Panel B: Univariate tests between princeling-backed and non-princeling-backed firms

\begin{tabular}{llll}
\hline Variables & With princelings & Without princelings & t-value \\
\hline Total bank loan & 0.18 & 0.13 & $3.46^{* * *}$ \\
Long-term bank loan & 0.08 & 0.06 & $2.95^{* * *}$ \\
Short-term bank loan & 0.08 & 0.07 & $2.16^{* *}$ \\
Investment growth & 0.15 & 0.07 & $2.26^{* *}$ \\
\hline
\end{tabular}

This table shows summary statistics and univariate test of key variables. Detailed definitions of all the variables are reported in Appendix A. 
Table 3. The impact of princelings connections on bank loan

\begin{tabular}{|c|c|c|c|c|c|c|}
\hline \multirow[t]{2}{*}{ VARIABLES } & \multicolumn{2}{|c|}{ Total bank loan } & \multicolumn{2}{|c|}{ Long-term bank loan } & \multicolumn{2}{|c|}{ Short-term bank loan } \\
\hline & 1 & 2 & 3 & 4 & 5 & 6 \\
\hline Princelings & $\begin{array}{l}0.089 * * * \\
(9.52)\end{array}$ & $\begin{array}{l}0.057 * * * \\
(4.45)\end{array}$ & $\begin{array}{l}0.042^{* * *} \\
(7.57)\end{array}$ & $\begin{array}{l}0.020 * * * \\
(2.59)\end{array}$ & $\begin{array}{l}0.033 * * * \\
(7.47)\end{array}$ & $\begin{array}{l}0.035^{* * *} \\
(5.73)\end{array}$ \\
\hline Princelings*SOE & & $\begin{array}{l}-0.066^{* * *} \\
(-3.55)\end{array}$ & & $\begin{array}{l}-0.047 * * * \\
(-4.18)\end{array}$ & & $\begin{array}{l}-0.004 \\
(-0.49)\end{array}$ \\
\hline SOE & & $\begin{array}{l}0.030 * * * \\
(5.95)\end{array}$ & & $\begin{array}{l}0.018 * * * \\
(6.18)\end{array}$ & & $\begin{array}{l}0.010^{* * * *} \\
(4.03)\end{array}$ \\
\hline Normal PC & $\begin{array}{l}0.025^{* * *} \\
(5.23)\end{array}$ & $\begin{array}{l}0.027^{* * * *} \\
(5.65)\end{array}$ & $\begin{array}{l}0.016 * * * \\
(5.84)\end{array}$ & $\begin{array}{l}0.018 * * * \\
(6.25)\end{array}$ & $\begin{array}{l}0.009 * * * \\
(3.82)\end{array}$ & $\begin{array}{l}0.009 * * * \\
(4.21)\end{array}$ \\
\hline $\mathrm{ROS}_{\mathrm{t}-1}$ & $\begin{array}{l}0.185^{* * * *} \\
(6.16)\end{array}$ & $\begin{array}{l}0.189 * * * \\
(6.49)\end{array}$ & $\begin{array}{l}0.070 * * * \\
(10.27)\end{array}$ & $\begin{array}{l}0.072 * * * \\
(10.62)\end{array}$ & $\begin{array}{l}0.104^{* * * *} \\
(9.07)\end{array}$ & $\begin{array}{l}0.105^{* * *} \\
(9.28)\end{array}$ \\
\hline Tobin’s $\mathrm{Q}_{\mathrm{t}-1}$ & $\begin{array}{l}0.028 * * * \\
(6.40)\end{array}$ & $\begin{array}{l}0.027^{* * *} \\
(6.22)\end{array}$ & $\begin{array}{l}0.016^{* * *} \\
(6.27)\end{array}$ & $\begin{array}{l}0.016^{* * *} \\
(6.09)\end{array}$ & $\begin{array}{l}0.009 * * * \\
(10.69)\end{array}$ & $\begin{array}{l}0.008 * * * \\
(10.55)\end{array}$ \\
\hline Size & $\begin{array}{l}0.216^{* * * *} \\
(4.80)\end{array}$ & $\begin{array}{l}0.219 * * * \\
(3.32)\end{array}$ & $\begin{array}{l}0.105^{* * * *} \\
(7.28)\end{array}$ & $\begin{array}{l}0.107^{* * * *} \\
(6.35)\end{array}$ & $\begin{array}{l}0.097 * * * \\
(9.36)\end{array}$ & $\begin{array}{l}0.098 * * * \\
(7.76)\end{array}$ \\
\hline Tangibility & $\begin{array}{l}0.221^{* * * *} \\
(5.20)\end{array}$ & $\begin{array}{l}0.226^{* * *} \\
(5.53)\end{array}$ & $\begin{array}{l}0.124^{* * *} \\
(4.35)\end{array}$ & $\begin{array}{l}0.127^{* * *} \\
(4.68)\end{array}$ & $\begin{array}{l}0.071^{* * *} \\
(10.24)\end{array}$ & $\begin{array}{l}0.073^{* * *} \\
(10.55)\end{array}$ \\
\hline Board & $\begin{array}{l}0.018^{* *} \\
(2.11)\end{array}$ & $\begin{array}{l}0.017 * \\
(1.70)\end{array}$ & $\begin{array}{l}0.008 * \\
(1.87)\end{array}$ & $\begin{array}{l}0.007 \\
(1.46)\end{array}$ & $\begin{array}{l}0.008 \\
(1.29)\end{array}$ & $\begin{array}{l}0.007^{*} \\
(1.91)\end{array}$ \\
\hline Independence & $\begin{array}{l}0.057 \\
(0.43)\end{array}$ & $\begin{array}{l}0.058 \\
(0.47)\end{array}$ & $\begin{array}{l}0.023 \\
(0.16)\end{array}$ & $\begin{array}{l}0.024 \\
(0.22)\end{array}$ & $\begin{array}{l}0.029 \\
(1.01)\end{array}$ & $\begin{array}{l}0.029 \\
(0.99)\end{array}$ \\
\hline Constant & $\begin{array}{l}-4.640^{* * *} \\
(-9.83)\end{array}$ & $\begin{array}{l}-4.691 * * * \\
(-9.07)\end{array}$ & $\begin{array}{l}-2.266^{* * *} \\
(-7.29)\end{array}$ & $\begin{array}{l}-2.297 * * * \\
(-7.87)\end{array}$ & $\begin{array}{l}-2.052 * * * \\
(-8.48)\end{array}$ & $\begin{array}{l}-2.073^{* * * *} \\
(-8.64)\end{array}$ \\
\hline Year & Yes & Yes & Yes & Yes & Yes & Yes \\
\hline Industry & Yes & Yes & Yes & Yes & Yes & Yes \\
\hline Adjusted $\mathrm{R}^{2}$ & 0.473 & 0.474 & 0.412 & 0.413 & 0.426 & 0.427 \\
\hline Observations & 16,976 & 16,976 & 16,976 & 16,976 & 17,034 & 17,034 \\
\hline
\end{tabular}

This table shows the impact of princelings connections on the accessibility of total bank loans in column 1 and 2, on the accessibility of long-term loans in column 3 and 4, on the accessibility of short-term loans in column 5 and 6. The key independent variable Princelings is a dummy that measures the princelings connections of listed firms, which equals 1 if the firm is princeling-backed; $S O E$ is a dummy which equals 1 for SOEs and 0 for non-SOEs; Normal PC is a dummy that measures the normal political connections of listed firms; detailed definitions of all the variables are reported in Appendix A. T-statistics are reported in brackets below the coefficients. *, $* *$ and $* * *$ represent significance at the $10 \%, 5 \%$ and $1 \%$ levels. 
Table 4. The impact of princelings connections on bank lending decisions

\begin{tabular}{llll}
\hline VARIABLES & \multicolumn{3}{c}{ Total bank loan } \\
\cline { 2 - 4 } & All sample firms & SOEs & Non-SOEs \\
\hline Princelings & $0.085^{* * *}$ & $0.122^{* * *}$ & $0.029^{* * *}$ \\
& $(8.92)$ & $(6.95)$ & $(4.87)$ \\
Princelings & $-0.084^{* *}$ & $-0.234^{* * *}$ & $-0.025^{* *}$ \\
ROS $_{\mathrm{t}-1}$ & $(-2.07)$ & $(-2.79)$ & $(-1.98)$ \\
ROS $_{\mathrm{t}-1}$ & $0.192^{* * *}$ & $0.359^{* * *}$ & $0.059^{* * *}$ \\
& $(6.12)$ & $(4.86)$ & $(8.66)$ \\
Normal PC & $0.025^{* * *}$ & $0.021^{* *}$ & 0.004 \\
& $(5.23)$ & $(2.39)$ & $(1.37)$ \\
Tobin's Q $\mathrm{t}-1$ & $0.028^{* * *}$ & $0.033^{* * *}$ & $0.007^{* * *}$ \\
& $(6.44)$ & $(9.53)$ & $(6.94)$ \\
Size & $0.216^{* * *}$ & $0.288^{* * *}$ & $0.101^{* * *}$ \\
& $(4.83)$ & $(4.57)$ & $(9.66)$ \\
Tangibility & $0.220^{* * *}$ & $0.323^{* * *}$ & $0.066^{* * *}$ \\
& $(5.15)$ & $(3.37)$ & $(6.56)$ \\
Board & $0.018^{* * *}$ & $0.021^{* *}$ & $0.003^{* *}$ \\
& $(9.14)$ & $(2.17)$ & $(2.07)$ \\
Independence & $0.058^{*}$ & 0.055 & 0.015 \\
& $(1.65)$ & $(0.88)$ & $(0.98)$ \\
Constant & $-4.641^{* * *}$ & $-6.133^{* * *}$ & $-2.130^{* * *}$ \\
Year & $(-9.85)$ & $(-7.05)$ & $(-5.29)$ \\
Industry & Yes & Yes & Yes \\
Chow test & Yes & Yes & Yes \\
Adjusted $\mathrm{R}^{2}$ & 0.473 & $4.73^{* *}$ & 0.397 \\
Observations & 16,976 & 0.530 & 8,713 \\
\hline
\end{tabular}

This table shows the impact of princelings connections on bank lending decisions in all listed firms, as well as SOEs and non-SOEs respectively. The dependent variable is total bank loan. The key independent variable Princelings is a dummy that measures the princelings connections of listed firms, which equals 1 if the firm is princelingbacked; ROS is return on sales that represent firm profitability; Normal PC is a dummy that measures the normal political connections of listed firms; detailed definitions of all the variables are reported in Appendix A. T-statistics are reported in brackets below the coefficients. $*$, ** and $* * *$ represent significance at the $10 \%, 5 \%$ and $1 \%$ levels. 
Table 5. The impact of princelings connections on investment decisions

\begin{tabular}{llll}
\hline \multirow{2}{*}{ VARIABLES } & \multicolumn{3}{c}{ Investment growth } \\
\cline { 2 - 4 } & All sample firms & SOEs & Non-SOEs \\
\hline Princelings & $0.137^{* *}$ & 0.006 & $0.253^{* *}$ \\
& $(2.09)$ & $(0.06)$ & $(2.48)$ \\
Princelings & $-0.094^{* * *}$ & -0.025 & $-0.145^{* * *}$ \\
*Tobin's Q $_{\mathrm{t}-1}$ & $(-3.33)$ & $(-0.52)$ & $(-3.89)$ \\
Tobin's Q $\mathrm{t}-1$ & $0.028^{* * *}$ & $0.027^{* *}$ & $0.029^{* * *}$ \\
& $(3.59)$ & $(2.07)$ & $(2.84)$ \\
Normal PC & -0.012 & -0.018 & -0.022 \\
& $(-0.57)$ & $(-0.58)$ & $(-0.73)$ \\
Leverage & $-0.193^{* * *}-1$ & -0.109 & $-0.209^{* * *}$ \\
& $(-3.87)$ & $(-1.46)$ & $(-2.95)$ \\
Size & $0.050^{* * *}$ & $0.050^{* * *}$ & $0.066^{* * *}$ \\
& $(5.17)$ & $(4.08)$ & $(3.90)$ \\
Tangibility & $0.761^{* * *}$ & $0.640^{* * *}$ & $0.892^{* * *}$ \\
& $(11.67)$ & $(7.69)$ & $(8.45)$ \\
Constant & $-0.797^{* * *}$ & $-0.934^{* * *}$ & $-1.164^{* * *}$ \\
& $(-3.66)$ & $(-3.28)$ & $(-3.11)$ \\
Year & Yes & Yes & Yes \\
Industry & Yes & Yes & Yes \\
Chow test & & $6.03^{* *}$ & \\
Adjusted $\mathrm{R}^{2}$ & 0.324 & 0.236 & 0.456 \\
Observations & 13,019 & 6,354 & 6,665 \\
\hline
\end{tabular}

This table shows the impact of princelings connections on investment growth in all listed firms, as well as SOEs and non-SOEs respectively. The dependent variable is investment growth measured by $\operatorname{Ln}\left(\mathrm{I}_{t} / \mathrm{I}_{\mathrm{t}-1}\right)$. The key independent variable Princelings is a dummy that measures the princelings connections of listed firms, which equals 1 if the firm is princeling-backed; Tobin's $Q$ is the ratio of the market assets value divided by the replacement cost of assets, representing investment opportunities; Normal PC is a dummy that measures the normal political connections of listed firms; detailed definitions of all the variables are reported in Appendix A. T-statistics are reported in brackets below the coefficients. ${ }^{*}, * *$ and $* * *$ represent significance at the $10 \%, 5 \%$ and $1 \%$ levels. 
Table 6. The influence of the anti-corruption campaign on princelings connections regarding bank lending decisions

\begin{tabular}{lllll}
\hline VARIABLES & \multicolumn{4}{c}{ Total bank loan } \\
\cline { 2 - 5 } & SOEs & \multicolumn{3}{c}{ Non-SOEs } \\
& Princelings & Non-princelings & Princelings & Non-princelings \\
\hline Campaign & 0.127 & $0.089^{* * *}$ & 0.022 & $0.034^{* * *}$ \\
& $(1.16)$ & $(4.58)$ & $(0.73)$ & $(4.06)$ \\
Campaign & $0.125^{* *}$ & 0.012 & $0.085^{* * *}$ & 0.016 \\
*ROS $_{\text {it-1 }}$ & $(2.30)$ & $(0.20)$ & $(3.07)$ & $(0.96)$ \\
ROS $_{\text {it-1 }}$ & $0.364^{* * *}$ & $0.336^{* * *}$ & $0.081^{* * *}$ & $0.054^{* * *}$ \\
& $(3.77)$ & $(12.94)$ & $(3.44)$ & $(7.21)$ \\
Normal PC & -0.000 & $0.023^{* * *}$ & 0.001 & $0.005^{*}$ \\
& $(-0.00)$ & $(2.64)$ & $(0.08)$ & $(1.69)$ \\
Tobin's Q & $0.087^{* * *} 1$ & $0.030^{* * *}$ & $0.015^{* * *}$ & $0.007^{* * *}$ \\
& $(5.09)$ & $(8.34)$ & $(3.45)$ & $(6.57)$ \\
Size & $0.419 * * *$ & $0.278^{* * *}$ & $0.130^{* * *}$ & $0.099^{* * *}$ \\
& $(22.74)$ & $(70.68)$ & $(17.99)$ & $(56.93)$ \\
Tangibility & 0.173 & $0.332^{* * *}$ & $0.085^{* *}$ & $0.065^{* * *}$ \\
& $(1.54)$ & $(13.51)$ & $(2.10)$ & $(6.28)$ \\
Board & -0.016 & $0.023^{* * *}$ & 0.001 & $0.002^{*}$ \\
& $(-0.88)$ & $(6.61)$ & $(0.21)$ & $(1.67)$ \\
Independence & 0.022 & $0.060^{* * *}$ & -0.002 & $0.013^{* * *}$ \\
& $(0.45)$ & $(6.41)$ & $(-0.10)$ & $(3.47)$ \\
Constant & $-8.707^{* * *}$ & $-5.915^{* * *}$ & $-2.725^{* * *}$ & $-2.086^{* * *}$ \\
& $(-3.02)$ & $(-6.26)$ & $(-8.01)$ & $(-5.47)$ \\
Year & Yes & Yes & Yes & Yes \\
Industry & Yes & Yes & Yes & Yes \\
Objusted ${ }^{2}$ & 0.713 & 0.519 & 0.583 & 0.389 \\
\hline & 441 & 7,822 & 494 & 8,219 \\
\hline
\end{tabular}

This table shows the influence of the anti-corruption campaign on princelings connections regarding bank lending decisions in SOEs and non-SOEs respectively. Column 1 and 3 report the results in princeling-backed firms, while column 2 and 4 report the results in non-princeling-backed firms. The dependent variable is total bank loan. The key independent variable Campaign is a dummy that equals 1 when it refers to years later than 2012; ROS is return on sales that represent firm profitability; Normal PC is a dummy that measures the normal political connections of listed firms; detailed definitions of all the variables are reported in Appendix A. T-statistics are reported in brackets below the coefficients. $*$, ** and $* * *$ represent significance at the $10 \%, 5 \%$ and $1 \%$ levels. 
Table 7. The influence of the anti-corruption campaign on princelings connections regarding corporate investment decisions

\begin{tabular}{|c|c|c|c|c|}
\hline \multirow[t]{3}{*}{ VARIABLES } & \multicolumn{4}{|c|}{ Investment Growth } \\
\hline & \multicolumn{2}{|l|}{ SOEs } & \multicolumn{2}{|l|}{ Non-SOEs } \\
\hline & Princelings & Non-princelings & Princelings & Non-princelings \\
\hline \multirow[t]{2}{*}{ Campaign } & 0.093 & $0.197 * * *$ & 0.384 & 0.043 \\
\hline & $(0.28)$ & $(2.66)$ & $(0.88)$ & $(0.46)$ \\
\hline Campaign & $0.137 *$ & 0.030 & $0.002 * *$ & 0.015 \\
\hline * Tobin's $\mathrm{Q}_{\mathrm{t}-1}$ & $(1.84)$ & $(1.16)$ & $(2.02)$ & $(0.90)$ \\
\hline \multirow[t]{2}{*}{ Tobin’s Q $\mathrm{t}-1$} & 0.006 & $0.033 * *$ & $0.247 * * *$ & $0.034 * * *$ \\
\hline & $(0.10)$ & $(2.33)$ & $(4.21)$ & $(2.69)$ \\
\hline \multirow[t]{2}{*}{ Normal PC } & -0.037 & -0.015 & 0.013 & -0.022 \\
\hline & $(-0.26)$ & $(-0.50)$ & $(0.09)$ & $(-0.71)$ \\
\hline \multirow[t]{2}{*}{ Leverage $_{\mathrm{t}-1}$} & -0.155 & -0.113 & -0.282 & $-0.206 * * *$ \\
\hline & $(-0.42)$ & $(-1.47)$ & $(-0.91)$ & $(-2.82)$ \\
\hline \multirow[t]{2}{*}{ Size } & 0.043 & $0.049 * * *$ & $0.201^{* *}$ & $0.061 * * *$ \\
\hline & $(0.77)$ & $(3.81)$ & $(2.49)$ & $(3.53)$ \\
\hline \multirow[t]{2}{*}{ Tangibility } & $1.361^{* * *}$ & $0.607 * * *$ & 0.274 & $0.954 * * *$ \\
\hline & $(3.66)$ & $(7.07)$ & $(0.56)$ & $(8.80)$ \\
\hline \multirow[t]{2}{*}{ Constant } & -0.014 & $-0.935 * * *$ & $-5.031 * * *$ & $-1.022 * * *$ \\
\hline & $(-0.01)$ & $(-3.18)$ & $(-2.90)$ & $(-2.66)$ \\
\hline Year & Yes & Yes & Yes & Yes \\
\hline Industry & Yes & Yes & Yes & Yes \\
\hline Adjusted $\mathrm{R}^{2}$ & 0.1875 & 0.2324 & 0.2910 & 0.4308 \\
\hline Observations & 441 & 7,822 & 494 & 8,219 \\
\hline
\end{tabular}

This table shows the influence of the anti-corruption campaign on princelings connections regarding corporate investment decisions in SOEs and non-SOEs respectively. Column 1 and 3 report the results in princeling-backed firms, while column 2 and 4 report the results in non-princeling-backed firms. The dependent variable is investment growth. The key independent variable Campaign is a dummy that equals 1 when it refers to years later than 2012; Tobin's $Q$ is the ratio of the market assets value divided by the replacement cost of assets, representing investment opportunities; Normal PC is a dummy that measures the normal political connections of listed firms; detailed definitions of all the variables are reported in Appendix A. Tstatistics are reported in brackets below the coefficients. *, ** and *** represent significance at the $10 \%, 5 \%$ and $1 \%$ levels. 
Table 8. The comparison between princelings shareholders and executives, regarding the impact of princelings connections on total bank loan

\begin{tabular}{|c|c|c|c|c|c|c|}
\hline \multirow[t]{2}{*}{ VARIABLES } & \multicolumn{6}{|c|}{ Total bank loan } \\
\hline & \multicolumn{2}{|c|}{$\begin{array}{l}\text { All sample firms } \\
\text { shareholder executive }\end{array}$} & \multicolumn{2}{|c|}{$\begin{array}{l}\text { SOEs } \\
\text { shareholder executive }\end{array}$} & \multicolumn{2}{|c|}{$\begin{array}{l}\text { Non-SOEs } \\
\text { shareholder executive }\end{array}$} \\
\hline Princelings & $\begin{array}{l}0.040 * * * \\
(4.04)\end{array}$ & $\begin{array}{l}0.354 * * * \\
(14.48)\end{array}$ & $\begin{array}{l}0.053 * * * \\
(2.68)\end{array}$ & $\begin{array}{l}0.326 * * * \\
(9.84)\end{array}$ & $\begin{array}{l}0.021 * * * \\
(3.57)\end{array}$ & $\begin{array}{l}0.201 * * * \\
(6.72)\end{array}$ \\
\hline Normal PC & $\begin{array}{l}0.025^{* * *} \\
(5.34)\end{array}$ & $\begin{array}{l}0.025^{* * *} \\
(5.14)\end{array}$ & $\begin{array}{l}0.024 * * * \\
(2.79)\end{array}$ & $\begin{array}{l}0.020 * * \\
(2.21)\end{array}$ & $\begin{array}{l}0.005^{*} \\
(1.86)\end{array}$ & $\begin{array}{l}0.003 \\
(1.13)\end{array}$ \\
\hline $\mathrm{ROS}_{\mathrm{t}-1}$ & $\begin{array}{l}0.177 * * * \\
(15.92)\end{array}$ & $\begin{array}{l}0.188 * * * \\
(15.62)\end{array}$ & $\begin{array}{l}0.327 * * * \\
(14.33)\end{array}$ & $\begin{array}{l}0.351^{* * *} \\
(14.39)\end{array}$ & $\begin{array}{l}0.060 * * * \\
(9.18)\end{array}$ & $\begin{array}{l}0.059 * * * \\
(8.53)\end{array}$ \\
\hline Tobin’s $\mathrm{Q}_{\mathrm{t}-1}$ & $\begin{array}{l}0.026^{* * * *} \\
(15.59)\end{array}$ & $\begin{array}{l}0.027 * * * \\
(15.30)\end{array}$ & $\begin{array}{l}0.031^{* * * *} \\
(8.89)\end{array}$ & $\begin{array}{l}0.031 * * * \\
(8.63)\end{array}$ & $\begin{array}{l}0.007 * * * \\
(7.02)\end{array}$ & $\begin{array}{l}0.006 * * * \\
(6.39)\end{array}$ \\
\hline Size & $\begin{array}{l}0.208 * * * \\
(92.60)\end{array}$ & $\begin{array}{l}0.215 * * * \\
(90.82)\end{array}$ & $\begin{array}{l}0.276 * * * \\
(72.09)\end{array}$ & $\begin{array}{l}0.286^{* * * *} \\
(71.64)\end{array}$ & $\begin{array}{l}0.100 * * * \\
(59.42)\end{array}$ & $\begin{array}{l}0.099 * * * \\
(56.94)\end{array}$ \\
\hline Tangibility & $\begin{array}{l}0.222 * * * \\
(15.66)\end{array}$ & $\begin{array}{l}0.227 * * * \\
(15.02)\end{array}$ & $\begin{array}{l}0.323 * * * \\
(13.65)\end{array}$ & $\begin{array}{l}0.336^{* * * *} \\
(13.39)\end{array}$ & $\begin{array}{l}0.069 * * * \\
(6.89)\end{array}$ & $\begin{array}{l}0.061^{* * * *} \\
(5.88)\end{array}$ \\
\hline Board & $\begin{array}{l}0.018^{* * * *} \\
(9.54)\end{array}$ & $\begin{array}{l}0.019 * * * \\
(9.47)\end{array}$ & $\begin{array}{l}0.022 * * * \\
(6.71)\end{array}$ & $\begin{array}{l}0.022 * * * \\
(6.32)\end{array}$ & $\begin{array}{l}0.002 \\
(1.59)\end{array}$ & $\begin{array}{l}0.003^{* *} \\
(2.26)\end{array}$ \\
\hline Independence & $\begin{array}{l}0.057 * * * \\
(10.73)\end{array}$ & $\begin{array}{l}0.061 * * * \\
(10.77)\end{array}$ & $\begin{array}{l}0.058 * * * \\
(6.39)\end{array}$ & $\begin{array}{l}0.059 * * * \\
(6.10)\end{array}$ & $\begin{array}{l}0.012 * * * \\
(3.12)\end{array}$ & $\begin{array}{l}0.016^{* * * *} \\
(4.28)\end{array}$ \\
\hline Constant & $\begin{array}{l}-4.444 * * * \\
(-9.55)\end{array}$ & $\begin{array}{l}-4.607 * * * \\
(-8.82)\end{array}$ & $\begin{array}{l}-5.877 * * * \\
(-6.61)\end{array}$ & $\begin{array}{l}-6.089 * * * \\
(-6.19)\end{array}$ & $\begin{array}{l}-2.103^{* * *} \\
(-5.92)\end{array}$ & $\begin{array}{l}-2.099 * * * \\
(-5.50)\end{array}$ \\
\hline Year & Yes & Yes & Yes & Yes & Yes & Yes \\
\hline Industry & Yes & Yes & Yes & Yes & Yes & Yes \\
\hline Adjusted $\mathrm{R}^{2}$ & 0.463 & 0.479 & 0.518 & 0.534 & 0.394 & 0.395 \\
\hline Observations & 16,836 & 16,178 & 8,141 & 7,941 & 8,695 & 8,237 \\
\hline
\end{tabular}

This table shows the impact of different types of princelings connections on the accessibility of total bank loans. The results of princelings shareholders are reported in column 1, 3 and 5.The results of princelings executives are reported in column 2, 4 and 6. The key independent variable Princelings is a dummy that measures the princelings connections of listed firms, which equals 1 if the firm is princelings connected; Normal PC is a dummy that measures the normal political connections of listed firms; detailed definitions of all the variables are reported in Appendix A. Tstatistics are reported in brackets below the coefficients. *, ** and *** represent significance at the $10 \%, 5 \%$ and $1 \%$ levels. 
Table 9. The comparison between princelings shareholders and executives, regarding the impact of princelings connections on bank lending decisions

\begin{tabular}{|c|c|c|c|c|c|c|}
\hline \multirow[t]{2}{*}{ VARIABLES } & \multicolumn{6}{|c|}{ Total bank loan } \\
\hline & \multicolumn{2}{|c|}{$\begin{array}{l}\text { All sample firms } \\
\text { shareholder executive }\end{array}$} & \multicolumn{2}{|c|}{$\begin{array}{l}\text { SOEs } \\
\text { shareholder executive }\end{array}$} & \multicolumn{2}{|c|}{$\begin{array}{l}\text { Non-SOEs } \\
\text { shareholder executive }\end{array}$} \\
\hline Princelings & $\begin{array}{l}0.038 * * * \\
(3.78)\end{array}$ & $\begin{array}{l}0.343 * * * \\
(11.99)\end{array}$ & $\begin{array}{l}0.049 * * \\
(2.48)\end{array}$ & $\begin{array}{l}0.302 * * * \\
(7.85)\end{array}$ & $\begin{array}{l}0.022 * * * \\
(3.69)\end{array}$ & $\begin{array}{l}0.440^{* * *} \\
(9.88)\end{array}$ \\
\hline Princelings & -0.049 & $-0.139 *$ & -0.142 & $-0.296 * *$ & -0.022 & $-3.330 * * *$ \\
\hline$* \mathrm{ROS}_{\mathrm{t}-1}$ & $(-1.22)$ & $(-1.75)$ & $(-1.63)$ & $(-2.24)$ & $(-0.96)$ & $(-7.22)$ \\
\hline $\mathrm{ROS}_{\mathrm{t}-1}$ & $\begin{array}{l}0.181^{* * * *} \\
(5.67)\end{array}$ & $\begin{array}{l}0.189 * * * \\
(5.64)\end{array}$ & $\begin{array}{l}0.336^{* * * *} \\
(4.29)\end{array}$ & $\begin{array}{l}0.354 * * * \\
(4.44)\end{array}$ & $\begin{array}{l}0.058 * * * \\
(8.56)\end{array}$ & $\begin{array}{l}0.058^{* * * *} \\
(8.42)\end{array}$ \\
\hline Normal PC & $\begin{array}{l}0.025^{* * * *} \\
(5.33)\end{array}$ & $\begin{array}{l}0.025 * * * \\
(5.15)\end{array}$ & $\begin{array}{l}0.024 * * * \\
(2.79)\end{array}$ & $\begin{array}{l}0.020^{* *} \\
(2.23)\end{array}$ & $\begin{array}{l}0.005^{*} \\
(1.85)\end{array}$ & $\begin{array}{l}0.004 \\
(1.37)\end{array}$ \\
\hline Tobin’s Q t-1 & $\begin{array}{l}0.026 * * * \\
(15.62)\end{array}$ & $\begin{array}{l}0.027 * * * \\
(15.28)\end{array}$ & $\begin{array}{l}0.031^{* * * *} \\
(8.94)\end{array}$ & $\begin{array}{l}0.031 * * * \\
(8.58)\end{array}$ & $\begin{array}{l}0.007 * * * \\
(6.99)\end{array}$ & $\begin{array}{l}0.006^{* * * *} \\
(6.45)\end{array}$ \\
\hline Size & $\begin{array}{l}0.208 * * * \\
(92.61)\end{array}$ & $\begin{array}{l}0.215 * * * \\
(90.81)\end{array}$ & $\begin{array}{l}0.277 * * * \\
(72.12)\end{array}$ & $\begin{array}{l}0.286 * * * \\
(71.62)\end{array}$ & $\begin{array}{l}0.100 * * * \\
(59.38)\end{array}$ & $\begin{array}{l}0.099 * * * \\
(56.93)\end{array}$ \\
\hline Tangibility & $\begin{array}{l}0.221 * * * \\
(15.63)\end{array}$ & $\begin{array}{l}0.227 * * * \\
(15.00)\end{array}$ & $\begin{array}{l}0.323 * * * \\
(13.64)\end{array}$ & $\begin{array}{l}0.335 * * * \\
(13.38)\end{array}$ & $\begin{array}{l}0.069 * * * \\
(6.91)\end{array}$ & $\begin{array}{l}0.063 * * * \\
(6.05)\end{array}$ \\
\hline Board & $\begin{array}{l}0.018 * * * \\
(9.55)\end{array}$ & $\begin{array}{l}0.019 * * * \\
(9.48)\end{array}$ & $\begin{array}{l}0.022 * * * \\
(6.67)\end{array}$ & $\begin{array}{l}0.022 * * * \\
(6.32)\end{array}$ & $\begin{array}{l}0.002 \\
(1.56)\end{array}$ & $\begin{array}{l}0.003^{* *} \\
(1.96)\end{array}$ \\
\hline Independence & $\begin{array}{l}0.058 * * * \\
(10.74)\end{array}$ & $\begin{array}{l}0.061^{* * *} \\
(10.77)\end{array}$ & $\begin{array}{l}0.058 * * * \\
(6.36)\end{array}$ & $\begin{array}{l}0.059 * * * \\
(6.09)\end{array}$ & $\begin{array}{l}0.011 * * * \\
(3.09)\end{array}$ & $\begin{array}{l}0.015 * * * \\
(4.05)\end{array}$ \\
\hline Constant & $\begin{array}{l}-4.445^{* * *} \\
(-9.56)\end{array}$ & $\begin{array}{l}-4.607^{* * *} \\
(-8.80)\end{array}$ & $\begin{array}{l}-5.880^{* * *} \\
(-6.63)\end{array}$ & $\begin{array}{l}-6.087 * * * \\
(-6.15)\end{array}$ & $\begin{array}{l}-2.103^{* * *} \\
(-5.89)\end{array}$ & $\begin{array}{l}-2.094 * * * \\
(-5.54)\end{array}$ \\
\hline Year & Yes & Yes & Yes & Yes & Yes & Yes \\
\hline Industry & Yes & Yes & Yes & Yes & Yes & Yes \\
\hline Adjusted $\mathrm{R}^{2}$ & 0.463 & 0.479 & 0.518 & 0.534 & 0.394 & 0.399 \\
\hline Observations & 16,836 & 16,178 & 8,141 & 7,941 & 8,695 & 8,237 \\
\hline
\end{tabular}

This table shows the impact of different types of princelings connections on bank lending decisions. The results of princelings shareholders are reported in column 1, 3 and 5.The results of princelings executives are reported in column 2, 4 and 6. The key independent variable Princelings is a dummy that measures the princelings connections of listed firms, which equals 1 if the firm is princelings connected; ROS is return on sales that represent firm profitability; Normal PC is a dummy that measures the normal political connections of listed firms; detailed definitions of all the variables are reported in Appendix A. T-statistics are reported in brackets below the coefficients. *, ** and $* * *$ represent significance at the $10 \%, 5 \%$ and $1 \%$ levels. 
Table 10. The comparison between princelings shareholders and executives, regarding the impact of princelings connections on investment decisions

\begin{tabular}{|c|c|c|c|c|c|c|}
\hline \multirow{3}{*}{$\begin{array}{l}\text { VARIABLES } \\
\text { Princelings }\end{array}$} & \multicolumn{6}{|c|}{ Investment growth } \\
\hline & \multicolumn{2}{|c|}{$\begin{array}{l}\text { All sample firms } \\
\text { shareholder executive }\end{array}$} & \multicolumn{2}{|c|}{$\begin{array}{l}\text { SOEs } \\
\text { shareholder executive }\end{array}$} & \multicolumn{2}{|c|}{$\begin{array}{l}\text { Non-SOEs } \\
\text { shareholder executive }\end{array}$} \\
\hline & $\begin{array}{l}0.099 \\
(0.67)\end{array}$ & $\begin{array}{l}0.134 * \\
(1.79)\end{array}$ & $\begin{array}{l}-0.058 \\
(-0.38)\end{array}$ & $\begin{array}{l}0.032 \\
(0.30)\end{array}$ & $\begin{array}{l}0.452 \\
(0.93)\end{array}$ & $\begin{array}{l}0.241^{* *} \\
(2.25)\end{array}$ \\
\hline Princelings & -0.043 & $-0.094 * * *$ & 0.007 & -0.038 & -0.367 & $-0.139 * * *$ \\
\hline *Tobin's $\mathrm{Q}_{\mathrm{t}-1}$ & $(-0.46)$ & $(-3.05)$ & $(0.07)$ & $(-0.66)$ & $(-1.15)$ & $(-3.54)$ \\
\hline Tobin’s $Q_{\mathrm{t}-1}$ & $\begin{array}{l}0.028 * * * \\
(3.61)\end{array}$ & $\begin{array}{l}0.027 * * * \\
(3.45)\end{array}$ & $\begin{array}{l}0.027 * * \\
(2.09)\end{array}$ & $\begin{array}{l}0.026 * * \\
(2.04)\end{array}$ & $\begin{array}{l}0.029 * * * \\
(2.86)\end{array}$ & $\begin{array}{l}0.027 * * * \\
(2.68)\end{array}$ \\
\hline Normal PC & $\begin{array}{l}-0.012 \\
(-0.59)\end{array}$ & $\begin{array}{l}-0.010 \\
(-0.48)\end{array}$ & $\begin{array}{l}-0.019 \\
(-0.61)\end{array}$ & $\begin{array}{l}-0.014 \\
(-0.45)\end{array}$ & $\begin{array}{l}-0.022 \\
(-0.75)\end{array}$ & $\begin{array}{l}-0.022 \\
(-0.71)\end{array}$ \\
\hline Leverage $_{\mathrm{t}-1}$ & $\begin{array}{l}-0.190 * * * \\
(-3.80)\end{array}$ & $\begin{array}{l}-0.195 * * * \\
(-3.83)\end{array}$ & $\begin{array}{l}-0.105 \\
(-1.39)\end{array}$ & $\begin{array}{l}-0.116 \\
(-1.53)\end{array}$ & $\begin{array}{l}-0.207 * * * \\
(-2.92)\end{array}$ & $\begin{array}{l}-0.205^{* * *} \\
(-2.82)\end{array}$ \\
\hline Size & $\begin{array}{l}0.050 * * * \\
(5.10)\end{array}$ & $\begin{array}{l}0.047 * * * \\
(4.81)\end{array}$ & $\begin{array}{l}0.051 * * * \\
(3.99)\end{array}$ & $\begin{array}{l}0.050 * * * \\
(4.01)\end{array}$ & $\begin{array}{l}0.066 * * * \\
(3.90)\end{array}$ & $\begin{array}{l}0.061 * * * \\
(3.52)\end{array}$ \\
\hline Tangibility & $\begin{array}{l}0.756 * * * \\
(-11.51)\end{array}$ & $\begin{array}{l}0.765 * * * \\
(11.48)\end{array}$ & $\begin{array}{l}0.632 * * * \\
(7.52)\end{array}$ & $\begin{array}{l}0.614 * * * \\
(7.23)\end{array}$ & $\begin{array}{l}0.895 * * * \\
(8.46)\end{array}$ & $\begin{array}{l}0.953 * * * \\
(8.80)\end{array}$ \\
\hline Constant & $\begin{array}{l}-0.808 * * * \\
(-3.66)\end{array}$ & $\begin{array}{l}-0.738 * * * \\
(-3.33)\end{array}$ & $\begin{array}{l}-0.949 * * * \\
(-3.26)\end{array}$ & $\begin{array}{l}-0.956 * * * \\
(-3.31)\end{array}$ & $\begin{array}{l}-1.168^{* * *} \\
(-3.11)\end{array}$ & $\begin{array}{l}-1.012 * * * \\
(-2.63)\end{array}$ \\
\hline Year & Yes & Yes & Yes & Yes & Yes & Yes \\
\hline Industry & Yes & Yes & Yes & Yes & Yes & Yes \\
\hline Adjusted $\mathrm{R}^{2}$ & 0.3210 & 0.3132 & 0.2316 & 0.2334 & 0.4528 & 0.4307 \\
\hline Observations & 12,903 & 12,486 & 6,253 & 6,140 & 6,650 & 6,346 \\
\hline
\end{tabular}

This table shows the impact of different types of princelings connections on bank lending decisions. The results of princelings shareholders are reported in column 1, 3 and 5.The results of princelings executives are reported in column 2, 4 and 6. The key independent variable Princelings is a dummy that measures the princelings connections of listed firms, which equals 1 if the firm is princelings connected; Tobin's $Q$ is the ratio of the market assets value divided by the replacement cost of assets, representing investment opportunities; Normal PC is a dummy that measures the normal political connections of listed firms; detailed definitions of all the variables are reported in Appendix A. T-statistics are reported in brackets below the coefficients. *, ** and ${ }^{* * *}$ represent significance at the $10 \%, 5 \%$ and $1 \%$ levels. 
Table 11. The impact of princelings connections in firms with or without normal political connections (NPC) regarding bank lending decisions

\begin{tabular}{|c|c|c|c|c|}
\hline \multirow[t]{3}{*}{ VARIABLES } & \multicolumn{4}{|c|}{ Total bank loan } \\
\hline & \multicolumn{2}{|l|}{ SOEs } & \multicolumn{2}{|l|}{ Non-SOEs } \\
\hline & With PC & Without PC & With PC & Without PC \\
\hline \multirow[t]{2}{*}{ Princelings } & $0.162 * * *$ & $0.111^{* * *}$ & $0.040 * * *$ & $0.025^{* * *}$ \\
\hline & $(4.40)$ & $(5.53)$ & $(2.96)$ & $(4.33)$ \\
\hline Princelings & 0.044 & $-0.268 * * *$ & -0.069 & $-0.015^{*}$ \\
\hline$* \mathrm{ROS}_{\mathrm{t}-1}$ & $(0.27)$ & $(-2.72)$ & $(-1.07)$ & $(-1.72)$ \\
\hline \multirow[t]{2}{*}{$\operatorname{ROS}_{t-1}$} & $0.330 * * *$ & $0.357 * * *$ & $0.054 * *$ & $0.053 * * *$ \\
\hline & $(7.60)$ & $(12.27)$ & $(2.56)$ & $(8.66)$ \\
\hline \multirow[t]{2}{*}{ Tobin’s $\mathrm{Q}_{\mathrm{t}-1}$} & $0.019 * * *$ & $0.037 * * *$ & 0.002 & $0.006 * * *$ \\
\hline & $(2.83)$ & $(9.03)$ & $(0.72)$ & $(6.40)$ \\
\hline \multirow[t]{2}{*}{ Size } & $0.275^{* * *}$ & $0.291 * * *$ & $0.125 * * *$ & $0.084 * * *$ \\
\hline & (3.38) & (3.71) & (3.39) & $(4.86)$ \\
\hline \multirow[t]{2}{*}{ Tangibility } & $0.206 * * *$ & $0.365 * *$ & $0.091 * * *$ & $0.051 * * *$ \\
\hline & $(4.79)$ & $(2.41)$ & (3.88) & $(5.19)$ \\
\hline \multirow[t]{2}{*}{ Board } & $0.027 * * *$ & $0.017 * *$ & $0.006 * *$ & $0.007 * *$ \\
\hline & $(4.63)$ & $(2.21)$ & $(2.27)$ & $(2.32)$ \\
\hline \multirow[t]{2}{*}{ Independence } & 0.057 & $0.053^{*}$ & 0.003 & 0.020 \\
\hline & $(0.51)$ & $(1.82)$ & $(0.44)$ & (1.17) \\
\hline \multirow[t]{2}{*}{ Constant } & $-5.777 * * *$ & $-6.229 * * *$ & $-2.695 * * *$ & $-1.751 * * *$ \\
\hline & $(-3.78)$ & $(-6.79)$ & $(-3.94)$ & $(-4.82)$ \\
\hline Year & Yes & Yes & Yes & Yes \\
\hline Industry & Yes & Yes & Yes & Yes \\
\hline Adjusted $\mathrm{R}^{2}$ & 0.527 & 0.535 & 0.441 & 0.371 \\
\hline Observations & 2,271 & 5,992 & 2,756 & 5,957 \\
\hline
\end{tabular}

This table shows the impact of princelings connections on bank lending decisions in SOEs and non-SOEs respectively. Column 1 and 3 report the results in firms with normal political connections, while column 2 and 4 report the results in firms without normal political connections. The dependent variable is total bank loan. The key independent variable Princelings is a dummy that measures the princelings connections of listed firms, which equals 1 if the firm is princeling-backed; ROS is return on sales that represent firm profitability; detailed definitions of all the variables are reported in Appendix A. T-statistics are reported in brackets below the coefficients. $*$, ** and $* * *$ represent significance at the $10 \%, 5 \%$ and $1 \%$ levels. 
Table 12. The impact of princelings connections in firms with or without normal political connections (PC) regarding corporate investment decisions

\begin{tabular}{|c|c|c|c|c|}
\hline \multirow[t]{3}{*}{ VARIABLES } & \multicolumn{4}{|c|}{ Investment Growth } \\
\hline & \multicolumn{2}{|l|}{ SOEs } & \multicolumn{2}{|c|}{ Non-SOEs } \\
\hline & With PC & Without PC & With PC & Without PC \\
\hline \multirow[t]{2}{*}{ Princelings } & 0.021 & -0.005 & -0.208 & $0.303 * *$ \\
\hline & $(0.12)$ & $(-0.05)$ & $(-1.09)$ & $(2.42)$ \\
\hline \multirow{2}{*}{$\begin{array}{l}\text { Princelings } \\
\text { * Tobin's Q }\end{array}$} & -0.077 & -0.006 & $-0.141 *$ & $-0.152 * * *$ \\
\hline & $(-0.75)$ & $(-0.11)$ & $(-1.71)$ & $(-3.56)$ \\
\hline \multirow[t]{2}{*}{ Tobin’s Q $\mathrm{t}-1$} & 0.033 & 0.024 & $0.041 * *$ & $0.025 * *$ \\
\hline & $(1.21)$ & (1.59) & $(2.37)$ & $(1.96)$ \\
\hline \multirow[t]{2}{*}{ Leverage $_{\mathrm{t}-1}$} & -0.031 & -0.134 & -0.194 & $-0.208 * *$ \\
\hline & $(-0.18)$ & $(-1.60)$ & $(-1.41)$ & $(-2.47)$ \\
\hline \multirow[t]{2}{*}{ Size } & $0.057 * *$ & $0.046 * * *$ & $0.065 * *$ & $0.071^{* * *}$ \\
\hline & $(2.25)$ & $(3.23)$ & $(2.49)$ & $(3.14)$ \\
\hline \multirow[t]{2}{*}{ Tangibility } & $0.662 * * *$ & $0.635 * * *$ & $1.107 * * *$ & $0.791^{* * *}$ \\
\hline & $(4.06)$ & $(6.44)$ & $(6.30)$ & $(5.93)$ \\
\hline \multirow[t]{2}{*}{ Constant } & $-1.210 * *$ & $-0.802 * *$ & $-1.124^{*}$ & $-1.277^{* *}$ \\
\hline & $(-2.14)$ & $(-2.38)$ & $(-1.96)$ & $(-2.55)$ \\
\hline Year & Yes & Yes & Yes & Yes \\
\hline Industry & Yes & Yes & Yes & Yes \\
\hline Adjusted $\mathrm{R}^{2}$ & 0.157 & 0.233 & 0.566 & 0.411 \\
\hline Observations & 1,712 & 4,642 & 2,210 & 4,455 \\
\hline
\end{tabular}

This table shows the impact of princelings connections on corporate investment decisions in SOEs and non-SOEs respectively. Column 1 and 3 report the results in firms with normal political connections, while column 2 and 4 report the results in firms without normal political connections. The dependent variable is investment growth measured by $\operatorname{Ln}\left(\mathrm{I}_{t} / \mathrm{I}_{\mathrm{t}-1}\right)$. The key independent variable Princelings is a dummy that measures the princelings connections of listed firms, which equals 1 if the firm is princeling-backed; Tobin's $Q$ is the ratio of the market assets value divided by the replacement cost of assets, representing investment opportunities; detailed definitions of all the variables are reported in Appendix A. T-statistics are reported in brackets below the coefficients. *, ** and *** represent significance at the $10 \%, 5 \%$ and $1 \%$ levels. 
Table 13. Difference in difference regression results

Panel A. Difference in difference regression results of the impacts of princelings connections on the level of access to bank loans

\begin{tabular}{llll}
\hline VARIABLES & & \multicolumn{2}{c}{ Total bank loans } \\
\hline & All sample firms & SOEs & Non-SOEs \\
\hline Princelings & $0.042^{* * *}$ & $0.058^{* * *}$ & $0.031^{* * *}$ \\
& $(6.43)$ & $(2.66)$ & $(3.54)$ \\
Princelings & $-0.201^{* *}$ & $-0.120^{*}$ & $-0.157^{* * *}$ \\
*Campaign & $(-2.23)$ & $(-1.96)$ & $(-3.14)$ \\
Campaign & $-0.060^{*}$ & $-0.149^{* * *}$ & $-0.042^{* * *}$ \\
& $(-1.81)$ & $(-6.49)$ & $(-4.03)$ \\
Normal PC & -0.011 & $0.024^{* *}$ & $0.007^{*}$ \\
& $(-0.74)$ & $(2.18)$ & $(1.73)$ \\
Tobin's Q & 0.004 & $0.070^{* * *}$ & $0.015^{* * *}$ \\
& $(0.77)$ & $(3.70)$ & $(9.51)$ \\
Size & $0.258^{* * *}$ & $0.305^{* * *}$ & $0.109^{* * *}$ \\
Tangibility & $(4.54)$ & $(6.53)$ & $(4.56)$ \\
& $0.263^{* * *}$ & $0.393^{* * *}$ & $0.096^{* * *}$ \\
Board & $(6.40)$ & $(3.30)$ & $(7.37)$ \\
& $0.010^{*}$ & $0.019^{*}$ & $0.003^{*}$ \\
Independence & $(1.71)$ & $(1.68)$ & $(1.67)$ \\
& 0.010 & 0.064 & $0.011^{* *}$ \\
Constant & $(0.63)$ & $(1.63)$ & $(2.20)$ \\
Year & $-5.453^{* * *}$ & $-6.568^{* * *}$ & $-2.297^{* * *}$ \\
Industry & $(-3.92)$ & $(-6.52)$ & $(-3.55)$ \\
Chow test & Yes & Yes & Yes \\
Adjusted R2 & 0.487 & Yes & Yes \\
Observations & 16,976 & $4.01^{* *}$ & \\
\hline
\end{tabular}

This table shows the difference in difference random effect model regression results of the impacts of princelings connections on the level of access to bank loans in SOEs and non-SOEs respectively. Column 1 reports the results in all sample firms, while columns 2 and 3 report the results in SOEs and non-SOEs. The dependent variable is total bank loans. The key independent variable Princelings is a dummy variable which equals 1 if the firm is princelings connected; Campaign is a dummy that equals 1 when it refers to years later than 2012; detailed definitions of all the variables are reported in Appendix A. T-statistics are reported in brackets below the coefficients. *, ** and $* * *$ represent significance at the $10 \%, 5 \%$ and $1 \%$ levels. 
Panel B. Difference in difference regression results of the impacts of princelings connections on investment growth

\begin{tabular}{llll}
\hline VARIABLES & & Investment growth \\
\hline & All sample firms & SOEs & Non-SOEs \\
\hline Princelings & -0.086 & -0.031 & -0.028 \\
& $(-0.48)$ & $(-0.43)$ & $(-0.29)$ \\
Princelings & $-0.167^{* *}$ & $-0.061^{*}$ & $-0.119^{* *}$ \\
*Campaign & $(-2.28)$ & $(-1.68)$ & $(-2.36)$ \\
Campaign & -0.252 & 0.065 & $-0.189^{* * *}$ \\
& $(-0.85)$ & $(0.69)$ & $(-2.94)$ \\
Normal PC & 0.040 & -0.024 & -0.043 \\
& $(0.56)$ & $(-0.73)$ & $(-1.14)$ \\
Leverage & -0.044 & -0.004 & $-0.168^{*}$ \\
& $(-0.31)$ & $(-0.05)$ & $(-1.69)$ \\
Size & $0.066^{* *}$ & $0.037^{* * *}$ & $0.054^{* *}$ \\
Tangibility & $(2.23)$ & $(2.81)$ & $(2.50)$ \\
& $0.491^{* *}$ & $0.717^{* * *}$ & $0.893^{* * *}$ \\
Constant & $(2.36)$ & $(7.96)$ & $(6.81)$ \\
& $-1.223^{*}$ & $-0.698^{* *}$ & $-0.904^{* *}$ \\
Year & $(-1.67)$ & $(-2.36)$ & $(-1.96)$ \\
Industry & Yes & Yes & Yes \\
Chow test & & Yes & Yes \\
Adjusted R2 & 0.200 & $3.90^{* *}$ & \\
Observations & 13,019 & 0.221 & 0.354 \\
\hline
\end{tabular}

This table shows the difference in difference random effect model regression results of the impacts of princelings connections on investment growth in SOEs and nonSOEs respectively. Column 1 report the results in all sample firms, while columns 2 and 3 report the results in SOEs and non-SOEs. The key independent variable Princelings is a dummy that measures the princelings connections of listed firms, which equals 1 if the firm is princelings connected; Campaign is a dummy that equals 1 when it refers to years later than 2012; Normal PC is a dummy that measures the normal political connections of listed firms; detailed definitions of all the variables are reported in Appendix A. T-statistics are reported in brackets below the coefficients. *, ** and $* * *$ represent significance at the $10 \%, 5 \%$ and $1 \%$ levels. 
Table 14. Robustness tests with different dependent variables

Panel A. The impact of princelings connections on changes in bank loan

\begin{tabular}{|c|c|c|c|c|c|c|}
\hline \multirow{2}{*}{$\begin{array}{l}\text { VARIABLES } \\
\text { Princelings }\end{array}$} & \multicolumn{2}{|c|}{$\Delta$ total bank loan } & \multicolumn{2}{|c|}{$\Delta$ long-term bank loan } & \multicolumn{2}{|c|}{$\Delta$ short-term bank loan } \\
\hline & $\begin{array}{l}0.710^{* * *} \\
(3.23)\end{array}$ & $\begin{array}{l}1.354^{* * * *} \\
(4.44)\end{array}$ & $\begin{array}{l}0.000 \\
(0.18)\end{array}$ & $\begin{array}{l}0.004 \\
(1.41)\end{array}$ & $\begin{array}{l}0.706 * * * \\
(3.24)\end{array}$ & $\begin{array}{l}1.352 * * * \\
(4.46)\end{array}$ \\
\hline $\begin{array}{l}\text { Princelings } \\
\text { *SOE }\end{array}$ & & $\begin{array}{l}-1.337 * * * \\
(-3.05)\end{array}$ & & $\begin{array}{l}-0.008^{*} \\
(-1.84)\end{array}$ & & $\begin{array}{l}-1.338 * * * \\
(-3.07)\end{array}$ \\
\hline SOE & & $\begin{array}{l}0.101 \\
(0.88)\end{array}$ & & $\begin{array}{l}0.004^{* * * *} \\
(3.28)\end{array}$ & & $\begin{array}{l}0.105 \\
(0.92)\end{array}$ \\
\hline Normal PC & $\begin{array}{l}0.020 \\
(0.19)\end{array}$ & $\begin{array}{l}0.021 \\
(0.20)\end{array}$ & $\begin{array}{l}0.002^{*} \\
(1.77)\end{array}$ & $\begin{array}{l}0.002 * * \\
(2.05)\end{array}$ & $\begin{array}{l}0.022 \\
(0.20)\end{array}$ & $\begin{array}{l}0.023 \\
(0.22)\end{array}$ \\
\hline $\mathrm{ROS}_{\mathrm{t}-1}$ & $\begin{array}{l}0.005^{* * *} \\
(3.06)\end{array}$ & $\begin{array}{l}0.003^{* * * *} \\
(3.07)\end{array}$ & $\begin{array}{l}0.001 * * \\
(2.30)\end{array}$ & $\begin{array}{l}0.001 * * \\
(2.33)\end{array}$ & $\begin{array}{l}0.003 * * * \\
(3.07)\end{array}$ & $\begin{array}{l}0.004^{* * * *} \\
(3.08)\end{array}$ \\
\hline Tobin’s $\mathrm{Q}_{\mathrm{t}-1}$ & $\begin{array}{l}0.195^{* * *} \\
(105.41)\end{array}$ & $\begin{array}{l}0.195 * * * \\
(105.47)\end{array}$ & $\begin{array}{l}0.000 \\
(0.64)\end{array}$ & $\begin{array}{l}0.000 \\
(0.74)\end{array}$ & $\begin{array}{l}0.195 * * * \\
(105.72)\end{array}$ & $\begin{array}{l}0.195^{* * *} \\
(105.78)\end{array}$ \\
\hline Size & $\begin{array}{l}0.093^{* *} \\
(2.12)\end{array}$ & $\begin{array}{l}0.095 * * \\
(2.09)\end{array}$ & $\begin{array}{l}0.005^{* * *} \\
(11.89)\end{array}$ & $\begin{array}{l}0.005^{* * * *} \\
(12.24)\end{array}$ & $\begin{array}{l}0.097 * * \\
(2.24)\end{array}$ & $\begin{array}{l}0.101^{* *} \\
(2.23)\end{array}$ \\
\hline Tangibility & $\begin{array}{l}0.054 \\
(0.16)\end{array}$ & $\begin{array}{l}0.058 \\
(0.18)\end{array}$ & $\begin{array}{l}0.020^{* * * *} \\
(6.28)\end{array}$ & $\begin{array}{l}0.020^{* * * *} \\
(6.07)\end{array}$ & $\begin{array}{l}0.073 \\
(0.22)\end{array}$ & $\begin{array}{l}0.078 \\
(0.24)\end{array}$ \\
\hline Board & $\begin{array}{l}-0.059 \\
(-1.33)\end{array}$ & $\begin{array}{l}-0.058 \\
(-1.31)\end{array}$ & $\begin{array}{l}-0.000 \\
(-0.22)\end{array}$ & $\begin{array}{l}-0.000 \\
(-0.44)\end{array}$ & $\begin{array}{l}-0.058 \\
(-1.33)\end{array}$ & $\begin{array}{l}-0.058 \\
(-1.31)\end{array}$ \\
\hline Independence & $\begin{array}{l}0.039 \\
(0.32)\end{array}$ & $\begin{array}{l}0.032 \\
(0.26)\end{array}$ & $\begin{array}{l}0.001 \\
(0.61)\end{array}$ & $\begin{array}{l}0.001 \\
(0.58)\end{array}$ & $\begin{array}{l}0.040 \\
(0.33)\end{array}$ & $\begin{array}{l}0.032 \\
(0.27)\end{array}$ \\
\hline Constant & $\begin{array}{l}2.454^{* *} \\
(2.57)\end{array}$ & $\begin{array}{l}2.475 * * \\
(2.52)\end{array}$ & $\begin{array}{l}0.100^{* * * *} \\
(10.60)\end{array}$ & $\begin{array}{l}0.106^{* * * *} \\
(10.97)\end{array}$ & $\begin{array}{l}2.548 * * * \\
(2.68)\end{array}$ & $\begin{array}{l}2.577 * * * \\
(2.64)\end{array}$ \\
\hline Year & Yes & Yes & Yes & Yes & Yes & Yes \\
\hline Industry & Yes & Yes & Yes & Yes & Yes & Yes \\
\hline Adjusted $\mathrm{R}^{2}$ & 0.437 & 0.437 & 0.365 & 0.372 & 0.437 & 0.437 \\
\hline Observations & 14,451 & 14,451 & 14,451 & 14,451 & 14,534 & 14,534 \\
\hline
\end{tabular}

This table shows the impact of princelings connections on change in total bank loan in column 1 and 2, on change in long-term bank loan in column 3 and 4, on change in short-term bank loan in column 5 and 6. The key independent variable Princelings is a dummy that measures the princelings connections of listed firms, which equals 1 if the firm is princeling-backed; $S O E$ is a dummy which equals 1 for SOEs and 0 for non-SOEs; Normal PC is a dummy that measures the normal political connections of listed firms; detailed definitions of all the variables are reported in Appendix A. Tstatistics are reported in brackets below the coefficients. *, ** and *** represent significance at the $10 \%, 5 \%$ and $1 \%$ levels. 
Panel B. The impact of princelings connections on bank lending decisions, with change in total bank loan to be the dependent variable

\begin{tabular}{llll}
\hline VARIABLES & \multicolumn{3}{c}{$\Delta$ total bank loan } \\
\cline { 2 - 4 } & All sample firms & SOEs & Non-SOEs \\
\hline Princelings & $0.649 * * *$ & 0.001 & $1.239 * * *$ \\
& $(2.95)$ & $(0.16)$ & $(2.90)$ \\
Princelings & $-0.686^{* * *}$ & 0.037 & $-0.678^{* * *}$ \\
ROS $_{\mathrm{t}-1}$ & $(-7.07)$ & $(1.61)$ & $(-4.99)$ \\
ROS $_{\mathrm{t}-1}$ & $0.010^{* * *}$ & $0.010^{* * *}$ & $0.011^{* * *}$ \\
& $(4.07)$ & $(3.29)$ & $(5.65)$ \\
Normal PC & 0.023 & -0.000 & 0.024 \\
& $(0.21)$ & $(-0.12)$ & $(0.12)$ \\
Tobin's Q $\mathrm{t}-1$ & $0.195^{* * *}$ & $0.005^{* * *}$ & $0.196^{* * *}$ \\
& $(105.82)$ & $(5.39)$ & $(75.37)$ \\
Size & $0.087^{* *}$ & $0.011^{* * *}$ & -0.075 \\
& $(2.00)$ & $(9.33)$ & $(-0.74)$ \\
Tangibility & 0.086 & $0.030^{* * *}$ & 0.510 \\
& $(0.26)$ & $(3.95)$ & $(0.72)$ \\
Board & -0.058 & $0.003^{* * *}$ & -0.128 \\
& $(-1.31)$ & $(2.67)$ & $(-1.40)$ \\
Independence & 0.028 & -0.005 & -0.023 \\
& $(0.23)$ & $(-1.62)$ & $(-0.09)$ \\
Constant & $2.351^{* *}$ & $-0.208^{* * *}$ & 2.602 \\
Year & $(2.46)$ & $(-8.29)$ & $(1.17)$ \\
Industry & Yes & Yes & Yes \\
Adjusted $\mathrm{R}^{2}$ & Yes & Yes & Yes \\
Observations & 0.439 & 0.425 & 0.440 \\
\hline
\end{tabular}

This table shows the impact of princelings connections on bank lending decisions in all listed firms, as well as SOEs and non-SOEs respectively. The dependent variable is change in total bank loan. The key independent variable Princelings is a dummy that measures the princelings connections of listed firms, which equals 1 if the firm is princeling-backed; ROS is return on sales that represent firm profitability; Normal PC is a dummy that measures the normal political connections of listed firms; detailed definitions of all the variables are reported in Appendix A. T-statistics are reported in brackets below the coefficients. *,** and $* * *$ represent significance at the $10 \%, 5 \%$ and $1 \%$ levels. 
Panel C. The impact of princelings connections on investment decisions, with change in investment expenditure to be the dependent variable

\begin{tabular}{|c|c|c|c|}
\hline \multirow[t]{2}{*}{ VARIABLES } & \multicolumn{3}{|c|}{$\Delta$ investment expenditure } \\
\hline & All sample firms & SOEs & Non-SOEs \\
\hline \multirow[t]{2}{*}{ Princelings } & 0.001 & 0.007 & 0.001 \\
\hline & $(0.08)$ & $(0.49)$ & $(0.04)$ \\
\hline Princelings & $-0.001 * *$ & -0.005 & $-0.001 * *$ \\
\hline *Tobin's $\mathrm{Q}_{\mathrm{t}-1}$ & $(-2.17)$ & $(-1.06)$ & $(-2.36)$ \\
\hline \multirow{2}{*}{ Tobin’s Q $\mathrm{t}-1$} & $0.001^{* * *}$ & $0.010^{* * *}$ & $0.001^{*}$ \\
\hline & $(2.86)$ & $(5.25)$ & $(1.76)$ \\
\hline \multirow[t]{2}{*}{ Normal PC } & -0.001 & -0.001 & 0.004 \\
\hline & $(-0.11)$ & $(-0.13)$ & $(0.36)$ \\
\hline \multirow[t]{2}{*}{ Leverage $_{t-1}$} & $-0.027 * * *$ & -0.002 & $-0.026 * * *$ \\
\hline & $(-32.52)$ & $(-0.23)$ & $(-25.39)$ \\
\hline \multirow[t]{2}{*}{ Size } & $0.004^{*}$ & $0.006 * *$ & $0.015 * * *$ \\
\hline & $(1.77)$ & $(2.54)$ & $(2.95)$ \\
\hline \multirow[t]{2}{*}{ Tangibility } & $0.044 * *$ & -0.021 & $0.074^{* *}$ \\
\hline & $(2.34)$ & $(-1.35)$ & $(2.00)$ \\
\hline \multirow[t]{2}{*}{ Constant } & $0.113^{* *}$ & $-0.123 * *$ & $0.345 * * *$ \\
\hline & $(2.09)$ & $(-2.41)$ & $(3.04)$ \\
\hline Year & Yes & Yes & Yes \\
\hline Industry & Yes & Yes & Yes \\
\hline Adjusted $\mathrm{R}^{2}$ & 0.423 & 0.362 & 0.645 \\
\hline Observations & 13,019 & 6,354 & 6,665 \\
\hline
\end{tabular}

This table shows the impact of princelings connections on change in investment expenditures in all listed firms, as well as SOEs and non-SOEs respectively. The dependent variable is change in investment expenditure. The key independent variable Princelings is a dummy that measures the princelings connections of listed firms, which equals 1 if the firm is princeling-backed; Tobin's $Q$ is the ratio of the market assets value divided by the replacement cost of assets, representing investment opportunities; Normal PC is a dummy that measures the normal political connections of listed firms; detailed definitions of all the variables are reported in Appendix A. Tstatistics are reported in brackets below the coefficients. *, ** and $* * *$ represent significance at the $10 \%, 5 \%$ and $1 \%$ levels. 


\section{Appendix A. Definition and calculation of variables}

Name of variables

\section{Panel A. Dependent variables}

Bank loan

Total bank loan

Long-term bank loan

Short-term bank loan

Investment growth

$\Delta$ total bank loan

$\Delta$ long-term bank loan

$\Delta$ short-term bank loan

$\Delta$ investment expenditure

Panel B. Independent variables

Princelings

SOE

Normal PC

Campaign

ROS

Tobin’s Q

Panel C. Control variables

Size

Tangibility

Leverage

Board

Independence

\section{Definition}

Includes total bank loan, long-term bank loan and short-term bank loan

Total bank loans scaled by total assets

Long-term bank loans scaled by total assets

Short-term bank loans scaled by total assets

Logarithm of investment expenditure divided by its one period lag

Total bank loans less its one period lag scaled by total assets

Long-term bank loans less its one period lag scaled by total assets

Short-term bank loans less its one period lag scaled by total assets

Investment expenditure less its one period lag scaled by total assets

A dummy variable that equals 1 if the firm has a princeling shareholder or executive

A dummy variable that equals 1 if the firm is a SOE, and equals 0 if the firm is a non-SOE

A dummy variable that equals 1 if the firm has an executive with governmental working experience

A dummy variable that equals 1 if referring to the period after the anti-corruption campaign

Total pre-tax profits to total sales

Market value of assets divided by the replacement cost of assets

Natural logarithm of total assets

Total fixed assets to total assets

Total liabilities to total assets

Number of directors on the board to total assets

Number of independent directors on the board to total number of directors to total assets 


\section{References}

Barboza D. and La Franiere S., 2012, 'Princelings' in China Use Family Ties to Gain Riches, The New York Times, May 18, 2012, Page A1 of the New York edition.

Berkman, H., Cole, R.A., Fu, L.J., 2010. Political connections and minority shareholder protection: evidence from securities market regulation in China. Journal of Financial and Quantitative Analysis. vol. 45, pp. 1391-1417.

Blau B., Brough T., Thomas D., 2013, Corporate lobbying, political connections and the bailout of banks, Journal of Banking \& Finance, vol. 37, pp. 3007-3017.

Boubakri N., Cosset J. C., Guedhami O., Saffar W., 2011, The political economy of residual state ownership in privatized firms: Evidence from emerging markets, Journal of Corporate Finance, vol. 17, pp. 244-258.

Boubakri N., Guedhami O., Mishra D., 2012, Political connections and the cost of equity, Journal of Corporate Finance, vol. 18, pp. 541-559.

Chen C., Ding Y., Kim C., 2010, High-level politically-connected firms, corruption and analyst forecast accuracy around the world, Journal of International Business Studies, vol. 41, pp. 1505-1524.

Chen, D., Guan, Y., Zhang, T., Zhao, G., 2017. Political connection of financial intermediary: evidence from China's IPO market. Journal of Banking \& Finance, vol. 76, pp. 15-31.

Chen C. J. P., Li Z. Q., Su X. J., Sun Z., 2011, Rent-seeking incentives, corporate political connections, and the control structure of private firms: Chinese evidence, Journal of Corporate Finance, vol. 17, pp. 229-243.

Chen S. M., Sun Z., Tang S., Wu D. H., 2011, Government intervention and investment efficiency: Evidence from China, Journal of Corporate Finance, vol. 17, pp. 259-271.

Chen T., Kung J. K., 2019, Busting the "Princelings": The Campaign Against Corruption in China's Primary Land Market, The Quarterly Journal of Economics, vol. 134, pp. 185-226.

Cheung Y. L., Rau P. R., Stouraitis A., 2010, Helping hand or grabbing hand? Central vs. local government shareholders in Chinese listed firms, Review of Finance, vol. 14, pp. 669-694.

Claessens S., Feijen E., Laeven L., 2008, Political connections and preferential access 
to finance: The role of campaign contributions, Journal of Financial Economics, vol. 88, pp. 554-580.

Cohen L. H., Malloy C. J., 2010, The Power of Alumni Networks, Harvard Business Review, vol. 10, pp. 34.

Cull R., Xu LC., 2005, Institutions, ownership, and finance: The determinants of profit reinvestment among Chinese firms, Journal of Financial Economics, vol. 77, pp. $117-146$.

Faccio M., 2010, Differences between politically connected and nonconnected firms: A cross-country analysis, Financial Management, vol. 39, pp. 905-928.

Faccio M., Masulis R., McConnell J., 2006, Political connections and corporate bailouts, Journal of Finance, vol. 61, pp. 2597-2635.

Fan J. P. H., Rui O. M., Zhao M. X., 2008, Public governance and corporate finance: Evidence from corruption cases, Journal of Comparative Economics, vol. 36, pp. 343-364.

Fan J. P. H., Wang T. J., Zhang T. Y., 2007, Politically connected CEOs, corporate governance, and Post-IPO performance of China's newly partially privatized firms, Journal of Financial Economics, vol. 84, pp. 330-357.

Ferris S. P., Houston R., Javakhadze D., 2019, It is a Sweetheart of a Deal: Political Connections and Corporate - Federal Contracting, Financial Review. vol. 54, pp. 5784.

Fisman, R., 2001. Estimating the value of political connections, American Economic Review, vol. 91, pp. 1095-1102.

Gary S., Harymawan I., Nowland J., 2014, Political and government connections on corporate boards in Australia: Good for business? Australian Journal of Management, vol. 10, pp. 1-24.

Goldman E., Rocholl J., So J., 2013, Politically connected boards of directors and the allocation of procurement contracts, Review of Finance, vol. 17, pp. 1617-1648.

Hung M., Wong T. J., Zhang F., 2015, The Value of Political Ties Versus Market Credibility: Evidence from Corporate Scandals in China. Contemporary Accounting Research, vol. 32, pp. 1641-1675. 
Li, K., Yue, H., Zhao, L., 2009. Ownership, institutions, and capital structure: evidence from China. Journal of Comparative Economics, vol. 37, pp. 471-490.

Liu, J., Uchida, K., Gao, R., 2012. Political connections and the long-term stock performance of Chinese IPOs. Journal of International Financial Markets, Institutions \& Money, vol. 22, pp. 814-833.

Liu Q. G., Luo T. P., Tian G., 2016, Political connections with corrupt government bureaucrats and corporate M\&A decisions: A natural experiment from the anticorruption cases in China, Pacific-Basin Finance Journal, vol. 37, pp. 52-80.

Liu Q. G., Luo J., Tian G., 2016, Managerial professional connections versus political connections: Evidence from firms' access to informal financing resources, Journal of Banking and Finance, vol. 41, pp. 179-200.

Liu Q., Pan X., Tian G., 2016, To what extent did the economic stimulus package influence bank lending and corporate investment decisions? Journal of Banking \& Finance, in press.

Liu Q. G., Tang J. H., Tian G. G., 2013, Does political capital create value in the IPO market? Evidence from China, Journal of Corporate Finance, vol. 23, pp. 395-413.

Maciel C. O., Camargo C., 2016, Social connection in organizations: the effects of local ties on job engagement and performance, RAUSP - Management Journal, vol. 51, pp. 377-385.

Mogiliansky A. L., 2002, Why firms pay occasional bribes: the connection economy, European Journal of Political Economy, vol. 18, pp. 47- 60.

Pan X. F., Tian G. G., 2017, Political connections and corporate investments: Evidence from the recent anti-corruption campaign in China, Journal of Banking and Finance, in press.

Shleifer A. and Vishny R. W., 1993, Corruption, Quarterly Journal of Economics, 108 (3): 599-617.

Ramalho, R., 2007. The persistence of corruption: evidence from the 1992 Presidential Impeachment in Brazil. Working Paper. World Bank.

Yang, Z., 2013. Do political connections add value to audit firms, evidence from IPO audits in China. Contemporary Accounting Research. vol. 30, pp. 891-921. 